University of New Hampshire

University of New Hampshire Scholars' Repository

Earth Systems Research Center

Institute for the Study of Earth, Oceans, and

Space (EOS)

8-1994

\title{
Modeling carbon biogeochemistry in agricultural soils
}

\author{
Changsheng Li \\ University of New Hampshire - Main Campus \\ Steve Frolking \\ University of New Hampshire - Main Campus, steve.frolking@unh.edu \\ Robert Harriss \\ University of New Hampshire - Main Campus
}

Follow this and additional works at: https://scholars.unh.edu/ersc

\section{Recommended Citation}

Li, C., S. Frolking, and R. Harriss (1994), Modeling carbon biogeochemistry in agricultural soils, Global Biogeochem. Cycles, 8(3), 237-254, doi:10.1029/94GB00767.

This Article is brought to you for free and open access by the Institute for the Study of Earth, Oceans, and Space (EOS) at University of New Hampshire Scholars' Repository. It has been accepted for inclusion in Earth Systems Research Center by an authorized administrator of University of New Hampshire Scholars' Repository. For more information, please contact Scholarly.Communication@unh.edu. 


\title{
Modeling carbon biogeochemistry in agricultural soils
}

\author{
Changsheng Li, Steve Frolking, and Robert Harriss \\ Institute for the Study of Earth, Oceans, and Space, University of New Hampshire, Durham
}

\begin{abstract}
An existing model of $\mathrm{C}$ and $\mathrm{N}$ dynamics in soils was supplemented with a plant growth submodel and cropping practice routines (fertilization, irrigation, tillage, crop rotation, and manure amendments) to study the biogeochemistry of soil carbon in arable lands. The new model was validated against field results for short-term (1-9 years) decomposition experiments, the seasonal pattern of soil $\mathrm{CO}_{2}$ respiration, and long-term (100 years) soil carbon storage dynamics. A series of sensitivity runs investigated the impact of varying agricultural practices on soil organic carbon (SOC) sequestration. The tests were simulated for corn (maize) plots over a range of soil and climate conditions typical of the United States. The largest carbon sequestration occurred with manure additions; the results were very sensitive to soil texture (more clay led to greater sequestration). Increased $\mathrm{N}$ fertilization generally enhanced carbon sequestration, but the results were sensitive to soil texture, initial soil carbon content, and annual precipitation.

Reduced tillage also generally (but not always) increased SOC content, though the results were very sensitive to soil texture, initial SOC content, and annual precipitation. A series of long-term simulations investigated the SOC equilibrium for various agricultural practices, soil and climate conditions, and crop rotations. Equilibrium SOC content increased with decreasing temperatures, increasing clay content, enhanced $\mathrm{N}$ fertilization, manure amendments, and crops with higher residue yield. Time to equilibrium appears to be one hundred to several hundred years. In all cases, equilibration time was longer for increasing SOC content than for decreasing SOC content. Efforts to enhance carbon sequestration in agricultural soils would do well to focus on those specific areas and agricultural practices with the greatest potential for increasing soil carbon content.
\end{abstract}

\section{Introduction}

The United States, along with many other nations, is in the initial stages of developing national action plans to address the issue of possible climate changes driven by increasing concentrations of atmospheric greenhouse gases [e.g., USDS, 1992]. Current analysis suggests that a wide variety of mitigation actions will be required, with each nation developing a comprehensive strategy based on economic, ecological, and technological considerations appropriate to their specific circumstances. In almost every country some effort will be made to manipulate the terrestrial carbon cycle in ways that enhance the uptake of atmospheric $\mathrm{CO}_{2}$ (e.g., reforestation) or reduce emissions (e.g., reduce deforestation rates).

The soil carbon pool in agricultural lands will be a major consideration in future efforts to manage the terrestrial environment as a more effective carbon sink. Cultivation of

Copyright 1994 by the American Geophysical Union.

Paper number 94GB00767.

0886-6236/94/94GB-00767\$10.00 soils can typically result in a loss over time of $\sim 30 \%$ of the column organic carbon [Schlesinger, 1986]. The dynamics and magnitude of changes in soil organic matter resulting from various agricultural practices have been studied at many locations (e.g. , see reviews by Campbell [1978], Stevenson [1986], Tate [1986], Lugo et al. [1986], and Jackson [1992]). Current global extrapolations suggest that conversion of natural ecosystems to agriculture results in a release of approximately 0.6-3.6 Gt C yr ${ }^{-1}$ to the atmosphere [Detwiler and Hall, 1988; Houghton et al., 1988]. For the period 1860-1980, Houghton et al. [1983] attributed $80 \%$ of the net biospheric $\mathrm{CO}_{2}$ source to decreased carbon storage in aboveground biomass and $20 \%$ to loss of soil organic matter.

Field experiments have demonstrated that there is a potential for reducing soil carbon losses from cultivated soils, and under certain conditions it has been possible to increase soil carbon levels through changes in agricultural management practices. For example, reduced or no-till methods, use of cover crops, and manure amendments can sometimes increase soil carbon levels and enhance soil fertility while maintaining acceptable crop yield [e.g., Bauer and Black, 1981; Reganold et al., 1987; Paustian et al., 1992]. Long-term experiments at Rothamsted, 
England, have demonstrated a three-fold increase in soil carbon storage in manured plots over a period of 140 years [Jenkinson, 1991]. A 70-year experiment on corn cultivation at Urbana, Illinois showed that crop rotation plus fertilization produced maximum crop yields and also maintained soil carbon at the highest levels [Odell et al., 1984].

A systematic assessment of the roles agricultural lands currently play in the global carbon cycle and of the future potential to conserve and sequester carbon by changing agricultural practices requires an integrated program of biogeochemical modeling and field experimentation [Barnwell et al., 1992; Jackson, 1992]. A complementary application of such modeling and assessment research would focus on developing site specific understanding and predictions of the kinds of practices that can be used to maintain and sustain soil fertility. This agricultural application is especially important in light of observed declines in world per capita food production [Brown, 1993]. In this paper we apply the Denitrification-Decomposition (DNDC) model [ $\mathrm{Li}$ et al., 1992a,b] to studies of carbon dynamics in agricultural soils. We report the first test and validation studies of DNDC for soil carbon and a systematic study of the sensitivity of soil carbon to various agricultural practices under varied soil and climate conditions.

\section{Structure of the DNDC Model}

DNDC [ $L i$ et al., 1992a] is a process-oriented simulation model of soil carbon and nitrogen biogeochemistry. The model contains four interacting submodels (Figure 1). The thermalhydraulic submodel uses soil physical properties, air temperature, and precipitation data to calculate soil temperature and moisture profiles and soil water fluxes through time. This information is fed to the denitrification submodel, the decomposition submodel, and/or the plant growth submodel. The denitrification submodel calculates hourly denitrification rates and nitrous oxide $\left(\mathrm{N}_{2} \mathrm{O}\right)$ and dinitrogen $\left(\mathrm{N}_{2}\right)$ production during periods when the soil has greater than $40 \%$ water-filled pore space. The decomposition submodel calculates daily decomposition, nitrification, ammonia volatilization processes, and $\mathrm{CO}_{2}$ production (soil microbial respiration). The plant growth submodel calculates daily root respiration, $\mathbf{N}$ uptake by plants, and plant growth.

In DNDC, soil organic carbon (SOC) resides in four major pools: plant residue or litter, microbial biomass, humads (or active humus), and passive humus. Each pool consists of one or more subpools with different properties (Table 1). The daily decomposition rate for each subpool is regulated by the pool size, its specific decomposition rate (SDR) or fraction lost per day, the soil clay content, $\mathrm{N}$ availability, soil temperature and moisture, and depth in the soil profile. When SOC in each pool decomposes, its carbon will be partially transferred to another SOC pool, partially assimilated into microbial biomass and partially converted into $\mathrm{CO}_{2}$. Soluble carbon is produced as an intermediate product during decomposition and is immediately consumed by microbial biomass in the soil. Meanwhile, the decomposed nitrogen will be partially transferred with the decomposed carbon to the next SOC pool and partially mineralized

\section{The DNDC Model}

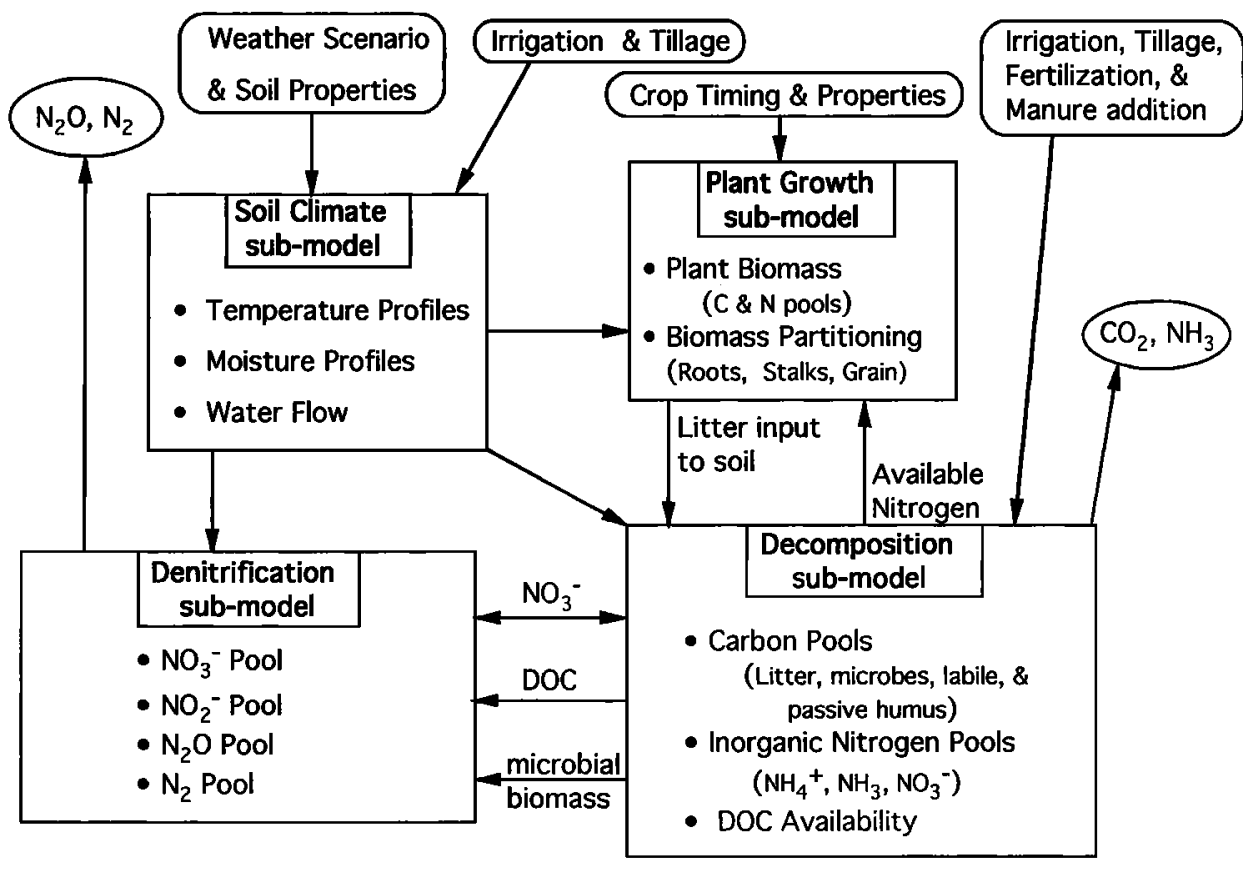

Figure 1. A simplified schematic diagram of the DNDC model. The thermal-hydraulic submodel converts climate data to a soil climate scenario. The decomposition submodel simulates decomposition of each SOC pool. The denitrification submodel simulates the processes reducing nitrate to nitrite, nitrous oxide, and dinitrogen. The cropping submodel simulates $\mathrm{C}$ and $\mathrm{N}$ exchanges at the plant/soil interface and the effects of agricultural practices on soil climate profile, decomposition, and denitrification. 
Table 1. Decomposition Parameters of the DNDC Model

\begin{tabular}{cllll}
\hline Pool & Component & $\begin{array}{l}\text { Initial } \\
\text { Fraction }\end{array}$ & $\mathrm{C} / \mathrm{N}$ & $\begin{array}{l}\mathrm{SDR}^{\mathrm{a}} \\
1 / \mathrm{d}\end{array}$ \\
\hline Residue & very labile & $\mathbf{0 . 0 8}$ & 2.35 & 0.074 \\
& $\begin{array}{llll}\text { labile } \\
\text { resistant }\end{array}$ & 0.32 & 20 & 0.074 \\
& & 0.60 & 20 & 0.02 \\
Microbial & labile & 0.90 & 8 & 0.33 \\
biomass & resistant & $\mathbf{0 . 1 0}$ & 8 & 0.04 \\
& & & & \\
Humads & labile & $\mathbf{0 . 1 6}$ & 8 & 0.16 \\
& resistant & 0.84 & 8 & 0.006 \\
\hline
\end{tabular}

Data from $L i$ et al. [1992a].

a SDR, specific decomposition rate.

to ammonium $\left(\mathrm{NH}_{4}{ }^{+}\right)$, which is then subject to nitrification. The free ammonium pool is in equilibrium with clay-adsorbed $\mathrm{NH}_{4}{ }^{+}$pool and any dissolved ammonia $\left(\mathrm{NH}_{3}\right)$ pool in the soil. The volatilization of $\mathrm{NH}_{3}$ to the atmosphere is controlled by soil temperature and moisture and $\mathrm{NH}_{3}$ concentration in soil water. When a rainfall occurs, free $\mathrm{NH}_{4}{ }^{+}$and $\mathrm{NO}_{3}{ }^{-}$can be leached into deeper layers along with soil water flow, and denitrification processes are initiated (consuming $\mathrm{NO}_{3}{ }^{-}$). The concentration and distribution of $\mathrm{NO}_{3}{ }^{-}$and $\mathrm{NH}_{4}{ }^{+}$in the soil profile are major factors determining the nitrogen uptake rate by plants during the growing season. $\mathrm{CO}_{2}$ produced at any depth is assumed to flux to the atmosphere the same day that it is generated. There is no gas phase diffusion for $\mathrm{CO}_{2}$ in the model.

The thermal-hydraulic, decomposition, and denitrification submodels are described in detail by $L i$ et al. [1992a]. The plant growth submodel is described below.

\section{Modeling the Exchange of $\mathbf{N}$ and $\mathbf{C}$ at the Soil/Plant Interface}

\section{Nitrogen Uptake by Plants}

In the DNDC model, nitrogen uptake by vegetation is the key process linking crop growth with climate and soil status. The daily $\mathrm{N}$ uptake rate is regulated by four factors: the crop potential maximum yield, the crop $\mathrm{C}: \mathrm{N}$ ratio, the crop growth curve, and the availability of dissolved inorganic nitrogen $\left(\mathrm{NO}_{3}{ }^{-}\right.$ and $\mathrm{NH}_{4}{ }^{+}$) in the soil profile.

Crop potential maximum grain yield (PMGY) is defined as the optimum grain yield (kilograms carbon per hectare) of a crop growing with sufficient water and nitrogen (the model assumes all other nutrients and light are always in adequate supply). The PMGY value has increased historically on account of the development of crop varieties. Current PMGY values are derived from the literature for major crops including corn, soybean, winter wheat, spring wheat, barley, sorghum, alfalfa, nonlegume hay, cotton, and sugarcane (Table 2). These yields are all based on field production data. A generalized crop grow curve [Watts and Hanks, 1978] is used for all crops except winter wheat (Figure 2). A similar curve is used for winter wheat, except that the vegetation is considered dormant from January 1 through March 31. Crop growth is calculated as follows. Potential maximum biomass yield (PMBY) is calculated from the PMGY value and the crop biomass partitioning ratios, as

$$
\mathrm{PMBY}=\mathrm{PMGY} / G_{f}
$$

where $G_{f}$ is the fraction of crop biomass $C$ that is in the grain $\mathrm{C}$ pool at harvest. Crop potential maximum $\mathrm{N}$ uptake (PMNU) is the potential maximum biomass yield divided by the crop $\mathrm{C}: \mathrm{N}$ ratio ( $\mathrm{RCN}$; see Table 2 ), as

$$
\mathrm{PMNU}=\mathrm{PMBY} / \mathrm{RCN}
$$

Table 2. Default Potential Maximum Yields, $\mathrm{C}$ and $\mathrm{N}$ Allocations, and

\begin{tabular}{|c|c|c|c|c|c|c|c|}
\hline \multirow[b]{2}{*}{ Crop } & \multirow{2}{*}{$\begin{array}{l}\text { Potential } \\
\text { Maximum } \\
\text { Yield, kg C/ha }\end{array}$} & \multicolumn{3}{|c|}{ C Allocation } & \multicolumn{3}{|c|}{ Ratio $\mathrm{C} / \mathrm{N}$} \\
\hline & & $\overline{\text { Grain }}$ & Straw & Root & $\overline{\text { Straw }}$ & Root & Crop \\
\hline Corn & 4000 & 0.30 & 0.44 & 0.26 & 72.5 & 85.0 & 48.9 \\
\hline Soybean & 1320 & 0.28 & 0.44 & 0.28 & 28.0 & 28.0 & 14.0 \\
\hline Wheat & 1600 & 0.28 & 0.42 & 0.30 & 50.0 & 50.0 & 18.8 \\
\hline Barley & 2080 & 0.35 & 0.38 & 0.27 & 50.0 & 50.0 & 20.8 \\
\hline Oats & 2000 & 0.28 & 0.42 & 0.30 & 50.0 & 50.0 & 14.7 \\
\hline Sorghum & 2400 & 0.41 & 0.34 & 0.24 & 33.3 & 85.0 & 28.8 \\
\hline Alfalfa & 6400 & & 0.59 & 0.41 & 14.1 & 14.1 & 12.5 \\
\hline Grass & 2800 & & 0.59 & 0.4 & 18.0 & 18.0 & 11.2 \\
\hline Cotton & 800 & 0.19 & 0.48 & 0.33 & 28.6 & 28.6 & 18.8 \\
\hline Sugarcane & 40000 & 0.21 & 0.47 & 0.33 & 248.9 & 248.9 & 218.8 \\
\hline
\end{tabular}
Ratio $\mathrm{C} / \mathrm{N}$ in Crops in the United States

Data derived from Buyanovsky and Wagner [1986], Foth [1962], Jenkinson [1991], Olson and Kurtz [1982], Tivy [1990], USDA [1984, 1989, 1991a, b], and Watts and Hanks [1978]. 


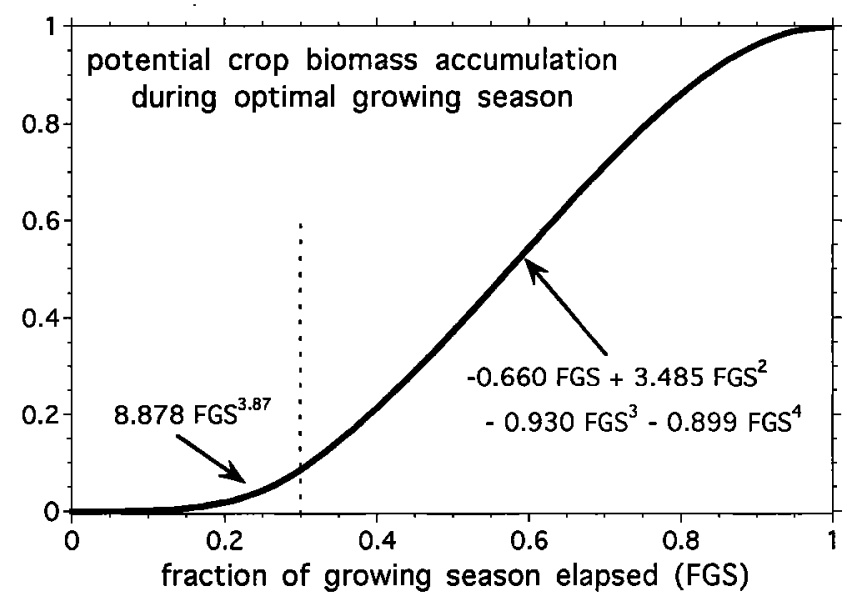

Figure 2. Optimal crop (biomass) growth curve as a function of elapsed fraction of growing season. Actual crop growth will be less than this if nitrogen is limiting. Source of function is Watts and Hanks [1978].

On a given day the potential $\mathrm{N}$ uptake $\left(\mathrm{N}_{\mathrm{up}}{ }^{*}\right)$ is determined by the difference between the optimal crop biomass $\mathrm{N}$ at that time and the actual crop $\mathrm{N}$ content, as

$$
\mathrm{N}_{\mathrm{up}}{ }^{*}=\mathrm{FG} \cdot \mathrm{PMNU}-\mathrm{N}_{\mathrm{crop}}
$$

where FG is the crop fractional growth (a function of time as shown in Figure 2), and $\mathrm{N}_{\text {crop }}$ is the crop biomass $\mathrm{N}$ at the beginning of the day. Nitrogen uptake is calculated layer by layer down the soil profile, and the demand in a given layer is proportional to that layer's root biomass, which is distributed such that $40 \%$ of the root biomass is in the top quarter of the total root depth, $30 \%$ is in the second quarter, $20 \%$ is in the third quarter, and $10 \%$ of root biomass is in the deepest quarter of total root depth [Molz and Remson, 1970].

Actual nitrogen uptake (and therefore plant growth) then depends on $\mathrm{N}$ availability. $\mathrm{NO}_{3}{ }^{-}$and $\mathrm{NH}_{4}{ }^{+}$are considered unavailable if the soil temperature is lower than $0^{\circ} \mathrm{C}$. If soil temperature is greater than $0^{\circ} \mathrm{C}$, the availability of $\mathrm{NO}_{3}{ }^{-}$and $\mathrm{NH}_{4}{ }^{+}$is regulated by their soil water solution concentrations and soil moisture. The fraction of the total dissolved inorganic nitrogen pool that is considered available to plants is equal to the value of the soil water-filled pore space (WFPS; i.e., at WFPS $=50 \%$, half the dissolved inorganic nitrogen is available for plant uptake). The proportion of $\mathrm{N}$ uptake from the $\mathrm{NO}_{3}{ }^{-}$ and $\mathrm{NH}_{4}{ }^{+}$pools is determined by their relative abundance. If the roots in a certain model layer cannot get enough nitrogen to meet their potential demand, the roots in the next deeper layer will try to absorb more to meet the daily total $\mathrm{N}$ uptake demand. The actual daily $\mathbf{N}$ uptake is the sum of the daily uptake from all layers. Since each day's nitrogen demand is determined as the difference between the current plant nitrogen and that day's potential maximum nitrogen content, poor growth due to suboptimal conditions early in the season can be recovered by optimal conditions later. This recovery can occur right up to harvest; there is no stunting of plants in the model. The actual annual $\mathrm{N}$-uptake is the sum of the daily uptake during the entire growing season.
In this model, for legume crops, such as soybeans and alfalfa, the annual $\mathrm{N}$ uptake from the atmosphere ( $\mathrm{N}$ fixation) is assumed to be equal to that from the soil [Hamilton et al., 1992]. Plant yield is still controlled by soil available nitrogen; that is, if soil available nitrogen cannot supply half the potential annual $\mathrm{N}$ uptake, legume crop yield is reduced.

\section{Allocation of $\mathbf{C}$ and $\mathbf{N}$ at Harvest}

Total crop biomass carbon resides in three pools: grain, roots, and the rest (stem, leaves, stalks, etc.). Crop biomass is partitioned into these pools, based on partitioning parameters (Table 2), at the end of the growing season (specified harvest date). Throughout the growing season the model keeps track only of the total crop $\mathbf{N}$ uptake, so crop biomass carbon is calculated at harvest time as the product of actual annual $\mathrm{N}$ uptake and the fixed crop $\mathrm{C}: \mathrm{N}$ ratio. The total biomass carbon is allocated to grain, straw/stalks, and roots (Table 2). At harvest, all of the grain is removed from the soil/plant system, and all of the roots stay in the soil. The percent of straw/stalks left in the field after harvest is a harvest practice input parameter. The straw/stalks left after harvest are assumed to stand inert in the field until the next tillage moves them into the soil.

\section{Root Respiration}

Root respiration is a result of three process: (1) root growth, (2) root maintenance, and (3) ion uptake and transport [Veen, 1981]. Osman [1971] observed that root respiration of wheat was an exponential function of temperature from $10^{\circ}-30^{\circ} \mathrm{C}$, with a $Q_{10}$ value of 2.5. Morris and Dacey [1984] observed decreases in root respiration as soil oxygen concentration decreased. Root respiration is modeled as

$$
\begin{gathered}
\mathrm{ROOTCO}_{2}=\left(R_{\mathrm{nu}} \bullet \mathrm{NU}+R_{\mathrm{rg}} \bullet \mathrm{RG}+R_{\mathrm{rb}} \bullet \mathrm{RB}\right) \\
2.5^{(\mathrm{T}-20) / 10} \bullet \mathrm{MF} \bullet \mathrm{ROOTAGE}
\end{gathered}
$$

where $\mathrm{ROOTCO}_{2}$ is the $\mathrm{CO}_{2}$ produced by root respiration (milligrams carbon per hectare per day), $R_{\mathrm{mu}}$ is the $\mathrm{CO}_{2}$ produced by roots due to $\mathrm{N}$ uptake (13.8 $\mathrm{mg} \mathrm{C} \mathrm{meq}^{-1} \mathrm{~N}$; Veen [1981]), $\mathrm{NU}$ is the plant daily $\mathrm{N}$ uptake (milliequivalents nitrogen per hectare per day), $R_{\mathrm{rg}}$ is the $\mathrm{CO}_{2}$ produced by roots due to root growth (19.19 $\mathrm{mg} \mathrm{C} \mathrm{g}^{-1}$ dry matter; Veen [1981]), RG is the daily root growth (grams dry matter per hectare per day), $R_{\mathrm{rb}}$ is the root maintenance respiration $\left(0.288 \mathrm{mg} \mathrm{C} \mathrm{g}^{-1}\right.$ dry matter $\mathrm{d}^{-1}$; Veen [1981]), RB is the living root biomass (grams dry matter per hectare), $T$ is the $15-\mathrm{cm}$ soil temperature $\left({ }^{\circ} \mathrm{C}\right)$, MF is a soil moisture proxy for oxygen availability (MF = 1 for WFPS $\leq 0.7 ; \mathrm{MF}=(1-\mathrm{WFPS}) / 0.3$ for WFPS $>0.7)$, and ROOTAGE is a factor for root age (as root cells age, respiration declines [Bijay-Singh and Gupta, 1977]) that drops linearly from one to zero as the plant goes from emergence to harvest.

\section{Modeling Effects of Cropping Practices on C and $\mathbf{N}$ Dynamics}

Agricultural practices simulated in DNDC are crop rotation. tillage, fertilization, manure amendment, and irrigation. Crop rotation, the sequential planting of different crops in a single field, generally involves changes in many of the other practices, as different crops have different irrigation, tillage, and fertilization 
demands. Modeling these other practices is described below. Tillage

Tilling practices are generalized into three categories: plowing, disking and mulching, characterized by their tilling depth and intensity of soil disturbance. With plowing, the soil is fully mixed from the surface to $25 \mathrm{~cm}$ [Wood and Edwards, 1992]. With disking, the soil is mixed from the surface to $12.5 \mathrm{~cm}$. With mulching, residues are mixed into the soil surface layer and the rest of the soil is not disturbed [Young, 1982]. Any conventional or conservation tillage system can be constructed by a combination of these three activities.

In the DNDC model, once soil is plowed or disked, several changes take place in the disturbed soil layers: (1) the soil from the surface to $25 \mathrm{~cm}$ (plowing) or $12.5 \mathrm{~cm}$ (disking) is completely mixed; residues, microbial biomass, humads, and passive humus above the tilling depth are redistributed uniformly over the tilling depth; (2) decomposition rates of residues, microbial biomass, and humads are increased by three times (plowing) or one and a half times (disking) [Fox and Bandel, 1986]; (3) soil moisture decreases by $20 \%$; (4) the denitrifier population decreases by $30 \%$ [Linn and Doran, 1984; Doran, 1980]; (5) $16 \%$ of resistant humads are converted into labile humads [Molina et al., 1983]. The changes primarily reflect the changes in soil structure and aeration due to tillage [Erickson, 1982]. We assume that subsequent rainfall events will erase the effects of tillage. Tillage effects 2, 3, and 4 all last until the fourth subsequent rainfall event, at which point they stop. Tillage effect 5 (transferring from resistant to labile humads) is gradually reduced ( $12 \%$ is transferred at the next rain, then $8 \%$, then $4 \%$ ). If the soil is only mulched, the residues left after harvest are incorporated into the top soil layer, without disturbing the soil profile.

\section{Fertilization}

Ammonium, nitrate, urea, and anhydrous ammonia are the potential fertilizer inputs in the DNDC model. The depth of application can be set as a model input parameter. Fertilizer mixed into the soil immediately enters active nitrogen pools; solid fertilizer applied to the soil surface is considered inert until the next rain/irrigation event.

Ammonium fertilizer enters the free $\mathrm{NH}_{4}{ }^{+}$pool to the depth of application and instantly redistributes into the clay-adsorbed $\mathrm{NH}_{4}{ }^{+}$pool and dissolved $\mathrm{NH}_{3}$ pool based on equilibrium partitioning constants [Li et al., 1992a]. Nitrate fertilizer enters the $\mathrm{NO}_{3}^{-}$pool to the depth of application. Urea enters the urea pool and is then hydrolyzed to $\mathrm{NH}_{4}{ }^{+}$. The hydrolysis rate is regulated by urea concentration and soil $p \mathrm{H}$. When anhydrous ammonia is injected into the soil, a fraction will directly volatilize into the atmosphere. The volatilization rate is regulated by anhydrous ammonia concentration and soil temperature. The rest of the anhydrous ammonia will enter the dissolved $\mathrm{NH}_{3}$ pool and instantly reach equilibrium with the free $\mathrm{NH}_{4}{ }^{+}$pool. The equilibrium is affected by $\mathrm{NH}_{3}$ and $\mathrm{NH}_{4}{ }^{+}$concentrations, soil $p \mathrm{H}$, and temperature. In DNDC it is assumed that only free $\mathrm{NH}_{4}{ }^{+}$and $\mathrm{NO}_{3}{ }^{-}$are available for microbial biomass and plants.

\section{Manure Amendment}

Manure sources include farmyard manure and green manure. According to Jenkinson [1990], the composition of farmyard manure is equivalent to $65 \%$ labile residue, $30 \%$ resistant residue, and $5 \%$ humads. Green manure is equivalent to fresh plant residue. Manure additions are directly added to these pools to the depth of application.

\section{Irrigation}

An irrigation event is equivalent to a rainfall event. The irrigation intensity is fixed at $0.5 \mathrm{~cm} \mathrm{~h}^{-1}$, and the irrigation duration controls the total volume of the water added. If a field is to be irrigated, an equivalent new "rainfall" event is added into the climate scenario.

\section{Validation of DNDC Simulations of Soil C Dynamics}

Six field studies have been chosen to test and validate the soil carbon dynamics simulated by DNDC. Cases 1 and 2 are of plant residue decomposition in bare soil. Cases 3 and 4 , annual soil $\mathrm{CO}_{2}$ flux studies, test the ability of the model to capture the seasonality of soil carbon cycling, the partitioning of decomposed SOC into the gas phase $\left(\mathrm{CO}_{2}\right)$, and the root respiration component of soil $\mathrm{CO}_{2}$ fluxes. Cases 5 and 6 are long term (86 and 150 years) soil carbon studies, testing the ability of the model to capture the effects of cropping and agricultural practices on soil carbon pools over many decades.

\section{Case 1: One-Year Residue Decomposition in Bare Soil} in Costa Rica

${ }^{14} \mathrm{C}$-labeled wheat straw was added at a rate of $2,000 \mathrm{~kg}$ $\mathrm{C} \mathrm{Ca}^{-1}$ to a silty clay soil in a bare farmland in Costa Rica, and the ${ }^{14} \mathrm{C}$-labeled residue remaining was measured monthly for the next year [Sauerbeck and Gonzalez, 1977]. The soil $p \mathrm{H}$ was 5.1, and $\mathrm{SOC}$ content (before the wheat straw amendment) was $0.067 \mathrm{~kg} \mathrm{C} \mathrm{kg}^{-1}$ soil. For the simulation a climate scenario was constructed from long-term monthly average temperatures and monthly precipitation for the year of the study [Instituto Meteorologico Nacional, 1988]. Annual total precipitation was $242.3 \mathrm{~cm}$, and annual average temperature was $22.0^{\circ} \mathrm{C}$; temperature variability was quite low through the year, and most precipitation fell from May to November.

Both the simulated results and the field data show that decomposition rates were very high initially but decreased rapidly during the following months (Figure 3). At the end of one year more than $60 \%$ of the added wheat straw residue had decomposed. On the basis of monthly values of remaining undecomposed residue, observed decomposition rates were initially higher than model rates (months 1-3), then observed rates were lower than model rates (months 4-8), and then observed and model rates were roughly equivalent (months 9-12). Two possible explanations for the discrepancies in the first eight months are: (1) improper partitioning of the residue into very labile, labile, and resistant fractions (see Table 2); and (2) pool SDR rates that are not correct either for wheat straw and/or tropical soils (model parameters in Table 2 are derived from temperate region studies of a variety of crops and plants). However, to avoid requiring an inordinate amount of site specific data, all of the parameters (SDR values and partitioning coefficients) are constant for all crops and all soils. In addition, the results at the end of the fiscal year are quite similar for field study and model, so for annual and longer simulations these initial differences become much less significant. 


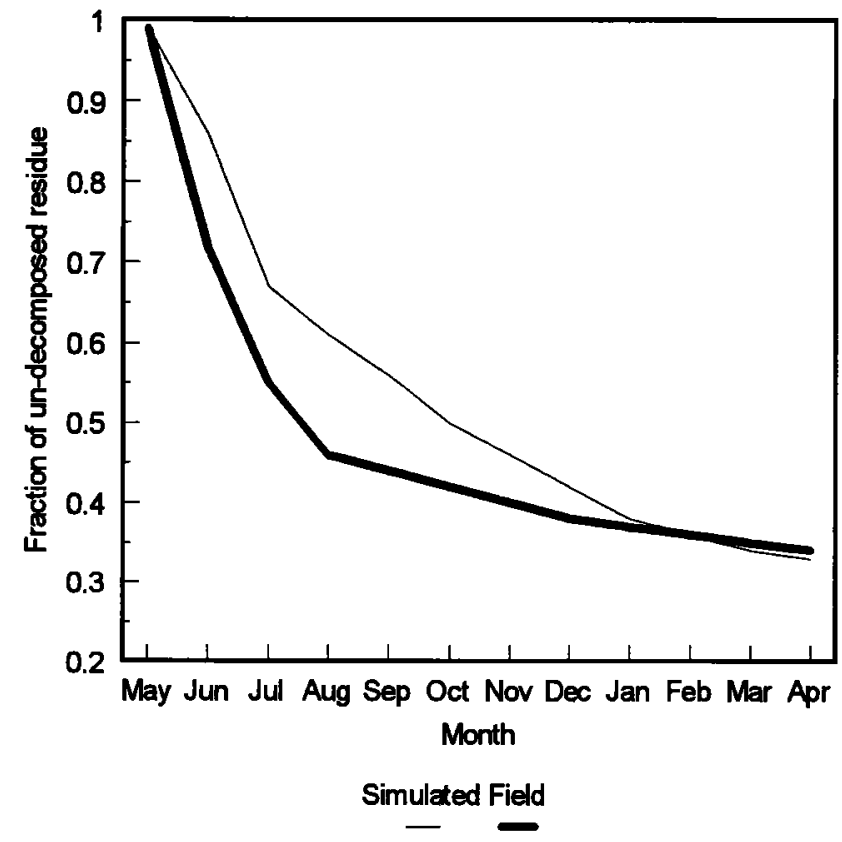

Figure 3. Comparison of simulated results and field data [Sauerbeck and Gonzalez, 1977] on decomposition of winter wheat residue in a silty clay soil in bare farmland in Costa Rica. Decomposition rates were very high initially, but decreased rapidly during the following months. About $40 \%$ of residue was left in the soil after 12-month decomposition.

Case 2: Nine-Year Residue Decomposition in Bare Soil in Germany

${ }^{14} \mathrm{C}$-labeled wheat straw was added (again, 2,000 kg C ha-1) to a sandy loam soil in a bare farmland at Bonn, Germany, and the remaining ${ }^{14} \mathrm{C}$-labeled residue was measured every year for the next nine years [Sauerbeck and Gonzalez, 1977]. The soil $p H$ was 6.7 , and the SOC was $0.0087 \mathrm{~kg} \mathrm{C} \mathrm{kg}^{-1}$ soil. For the simulation a climate scenario was constructed from long-term averages for Bonn [USDC, 1987]. Annual total precipitation is $58.1 \mathrm{~cm}$, and annual average temperature was $8.9^{\circ} \mathrm{C}$

As in the previous case, both the simulated results and field data show that $\sim 60 \%$ of the added residue decomposed during the first year (Figure 4). The decomposition rates gradually decreased during the subsequent eight years. Field and simulated results are in very good agreement.

\section{Case 3: $\mathrm{CO}_{2}$ Emissions from Grassland Soil in Germany}

Measurements of soil $\mathrm{CO}_{2}$ emissions were conducted for a one-year period in 1979 by Dorr and Munnich [1987] in a loamy, uncultivated grassland near Heidelberg, Germany. Monthly average emission rates were reported. Soil $p H$ was 6 , and total SOC content was $0.02 \mathrm{~kg} \mathrm{C} \mathrm{kg}^{-1}$ soil. A climate scenario for the simulation was constructed from 1971 to 1980 mean monthly climate (air temperature and precipitation) for the Heidelberg region [USDC, 1987]. The annual average temperature was $8.9^{\circ} \mathrm{C}$, and annual total precipitation was $58.1 \mathrm{~cm}$.

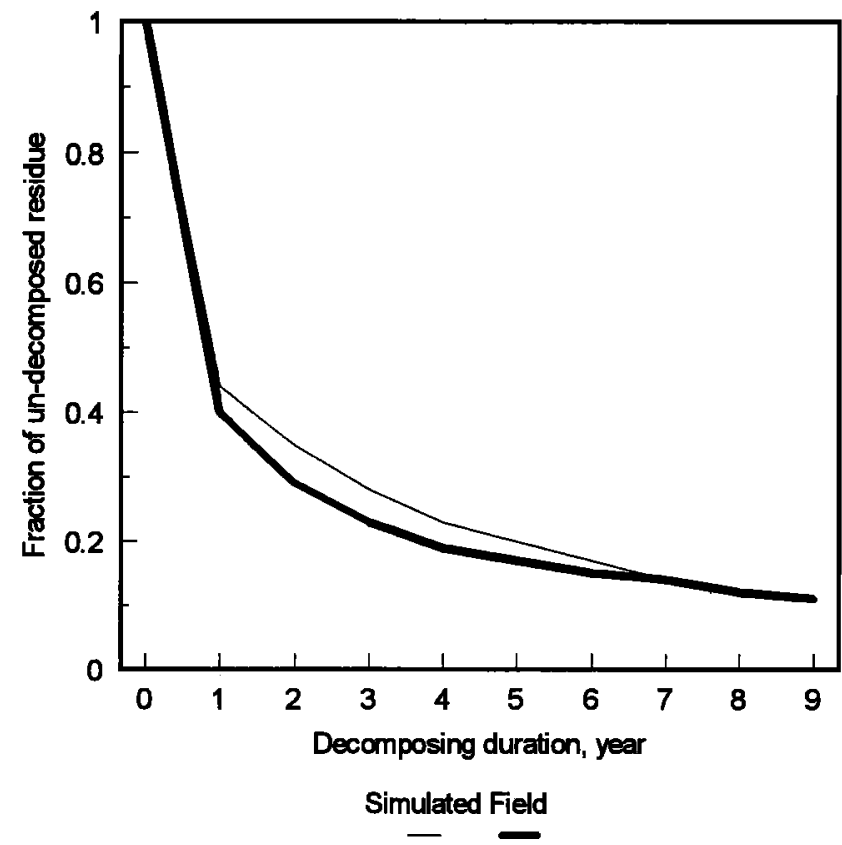

Figure 4. Comparison of simulated results and field data [Sauerbeck and Gonzalez, 1977] on decomposition of winter wheat residue in a sandy loam soil in bare farmland at Bonn, Germany. About $60 \%$ of the added residue decomposed during the first year. The decomposition rates gradually decreased during the subsequent eight years.

Both the simulated results and the field data show a strong seasonality in soil $\mathrm{CO}_{2}$ emissions (Figure 5). The maximum rates were about $35-40 \mathrm{~kg} \mathrm{C} \mathrm{ha}^{-1} \mathrm{~d}^{-1}$ in summer. While the simulated $\mathrm{CO}_{2}$ emission rate dropped to zero in winter (soil temperatures at or below $0^{\circ} \mathrm{C}$ ), the field $\mathrm{CO}_{2}$ emission rate was very low but measurable. The model underestimates the spring $\mathrm{CO}_{2}$ fluxes and slightly overestimates summer fluxes. This difference could be due, in part at least, to the inaccuracies of the climate scenario derived from long-term averages. However, the simulated annual $\mathrm{CO}_{2}$ flux $\left(7270 \mathrm{~kg} \mathrm{C} \mathrm{ha}^{-1}\right)$ is only slightly below the estimated annual field flux $(7880 \mathrm{~kg}$ $\mathrm{C} \mathrm{ha}^{-1}$ ). The contribution of root respiration to the total $\mathrm{CO}_{2}$ flux varied from $30 \%$ to $70 \%$ during the growing season. This range is consistent with field results [Turpin, 1920; Boois, 1974; Macfadyen, 1970; Kucera and Kirkham, 1971; Monteith et al., 1964].

\section{Case 4: $\mathrm{CO}_{2}$ Emissions from Cropland Soil in Missouri}

Measurements of soil $\mathrm{CO}_{2}$ emissions from a silty loam soil in a tilled and fertilized winter wheat field in Columbia, Missouri, were carried out by Buyanovsky et al. [1986]. Monthly averages of daily emission rates were reported. Total SOC was 0.012 $\mathrm{kg} \mathrm{C} \mathrm{kg}^{-1}$ soil. Fertilizer ( $50 \mathrm{~kg} \mathrm{~N} \mathrm{ha}^{-1}$ ) was added in October. Wheat was planted in October (yearday 288) and harvested at the end of June (yearday 196). Conventional tilling occurred before planting (disking on yearday 283) and after harvest (plowing on yearday 211). For the simulation a climate scenario was again constructed from long-term (39 year) averages [USDA, 1987] and is likely to differ from the actual weather during 


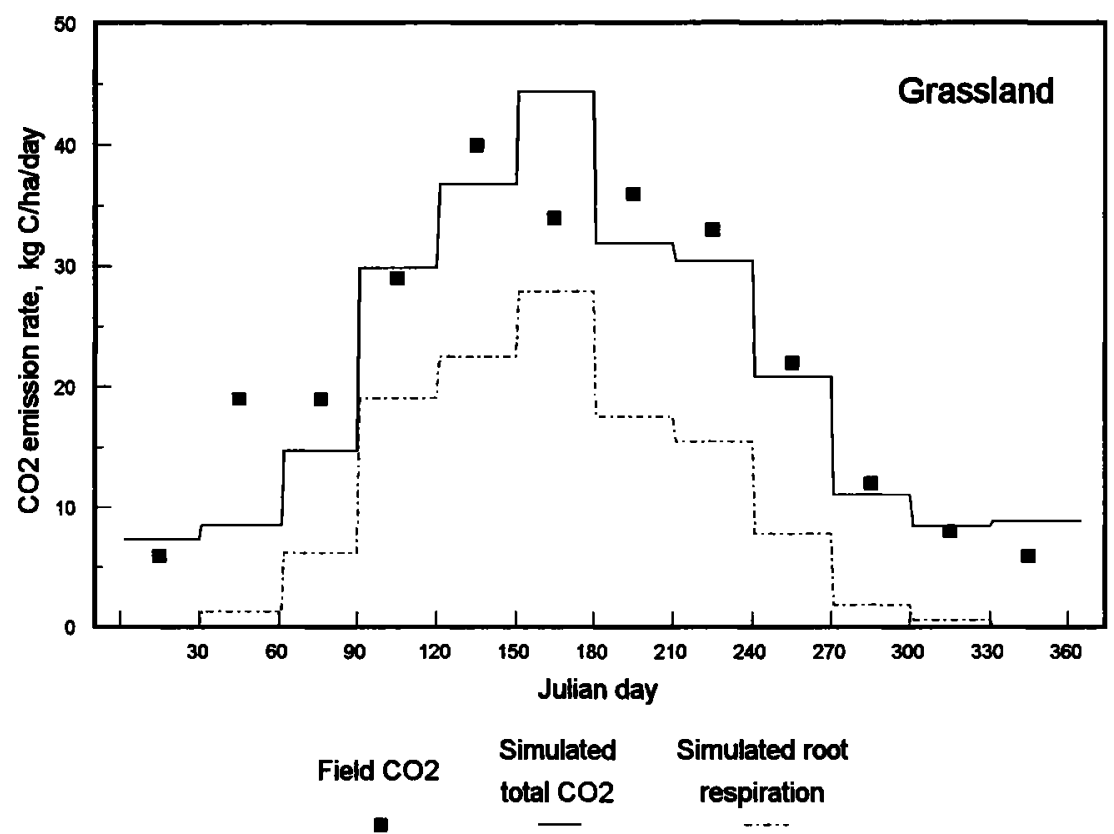

Figure 5. Comparison of simulated results and field data [Dorr and Munich, 1987] on soil $\mathrm{CO}_{2}$ emissions from a loamy, uncultivated grassland near Heidelberg, Germany. Both the results show a strong seasonality in $\mathrm{CO}_{2}$ emissions. The simulated results show that the contribution of root respiration to the total $\mathrm{CO}_{2}$ flux varied from $30 \%$ to $70 \%$ during the growing season.

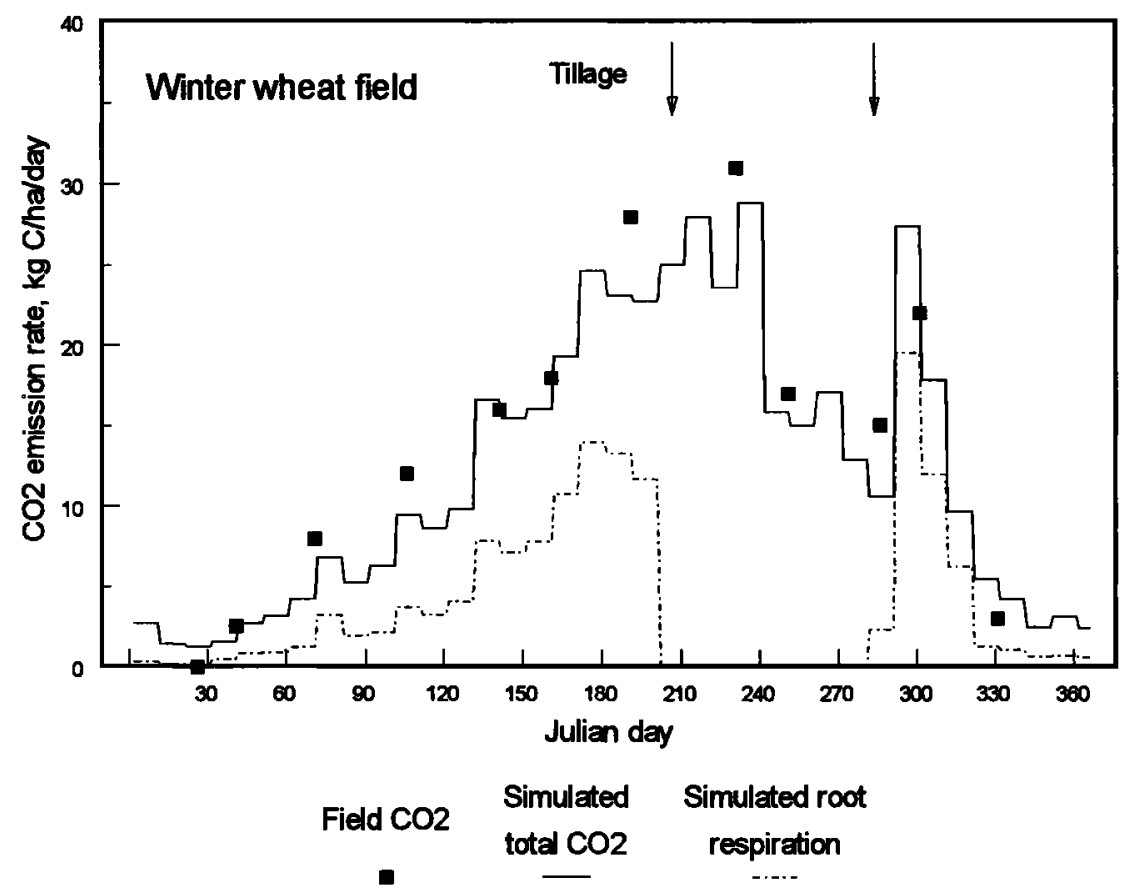

Figure 6. Comparison of simulated results and field data [Buyanovsky et al., 1986] on $\mathrm{CO}_{2}$ emissions from a silty loam soil in a tilled and fertilized winter wheat field in Columbia, Missouri. After the winter wheat was planted in October, $\mathrm{CO}_{2}$ emission rates increased due to tillage and root respiration of the young plants. Root respiration accounted for $30-70 \%$ of the $\mathrm{CO}_{2}$ flux. 
the field measurements in 1982. Annual total precipitation is $101.6 \mathrm{~cm}$, and annual average temperature is $12.8^{\circ} \mathrm{C}$ at the study area.

The field measured and simulated $\mathrm{CO}_{2}$ emission rates show similar seasonal patterns (Figure 6). With the seasonal drop in temperature, autumn emission rates decreased rapidly, but after the winter wheat was planted (October), $\mathrm{CO}_{2}$ emission rates increased. In the simulation this increase was due both to root respiration of the young plants and to increased microbial activity following soil disturbance during planting. Again, root respiration accounted for $30-70 \%$ of the $\mathrm{CO}_{2}$ flux.

Case 5: 86-Year Soil C Storage Dynamics in Croplands in Illinois

The Morrow Plots at University of Illinois at UrbanaChampaign, Illinois, are the oldest agronomic research plots in the United States and include the oldest continuous corn (maize) plot in the world. For more than 100 years the effects of cropping system and soil treatment upon crop yields and certain soil properties have been closely monitored. Three plots were chosen from the Morrow Plots to validate the DNDC model. SOC was measured at the three plots with different crop rotations in the agricultural experiment station from 1904 to 1990 . On the plots, soil texture is silt loam and pH is 5.8 [USDA, 1984, 1992]. Nitrogen concentration in the rainfall is $1.8 \mathrm{mg} \mathrm{N}^{-1}$ [NAPAP, 1988].

On plot 3 corn has been grown continuously since 1876 . The plot has been conventionally plowed once a year in the fall. In 1904 the $\mathrm{SOC}$ was $0.024 \mathrm{~kg} \mathrm{C} \mathrm{kg}^{-1}$ soil.
Plot 4 grew corn and oats from 1876 through 1966. From 1904 through 1966 , legume cover crops, predominantly sweet clover or alfalfa, were seeded as winter cover after the oat harvest and plowed under the following spring before planting corn. In 1967 the crop rotation on plot 4 was changed to corn and soybeans. Corn and oats were each conventionally plowed once a year, and the soybeans were disked once a year at seeding time. In 1904 the $\mathrm{SOC}$ was $0.026 \mathrm{~kg} \mathrm{C} \mathrm{kg}^{-1}$ soil.

Plot 5 grew corn, oats, and clover in no regular sequence until 1901 when a three-year rotation of corn, oats, and clover was initiated. In 1954, alfalfa replaced clover in the plot 5 rotation. Corn and oats were conventionally plowed once a year in fall, but clover and alfalfa were not tilled. In 1904 the SOC was $0.034 \mathrm{~kg} \mathrm{C} \mathrm{kg}^{-1}$ soil.

For all plots, until 1955 only crop stubble and root residues were returned to the soil. Beginning in 1955, crop residues (including straw and stalks) were returned to the soil on all of the plots. Neither fertilizer nor manure was applied on the three plots. Because of the introduction of new varieties, corn yield increased from $540 \mathrm{~kg}_{\text {grain }} \mathrm{C} \mathrm{ha}^{-1}$ ( 20 bushels acre $\left.{ }^{-1}\right)$ in 1930 to $1340 \mathrm{~kg}$ grain C ha-1 $\left(50\right.$ bushels acre $\left.{ }^{-1}\right)$ in 1980 .

For the simulation, an 86-year climate scenario was constructed based on the data of mean monthly precipitation and temperature at Urbana from 1904 to 1990 , recorded by the Illinois State Water Survey. An 86-year simulation was conducted for each plot, based on its cropping practices. Both the simulated results and field data show that SOC contents decreased rapidly from 1904 to 1955 and approached equilibrium from 1955 to 1990 at all three plots (Figure 7). The only change in cropping

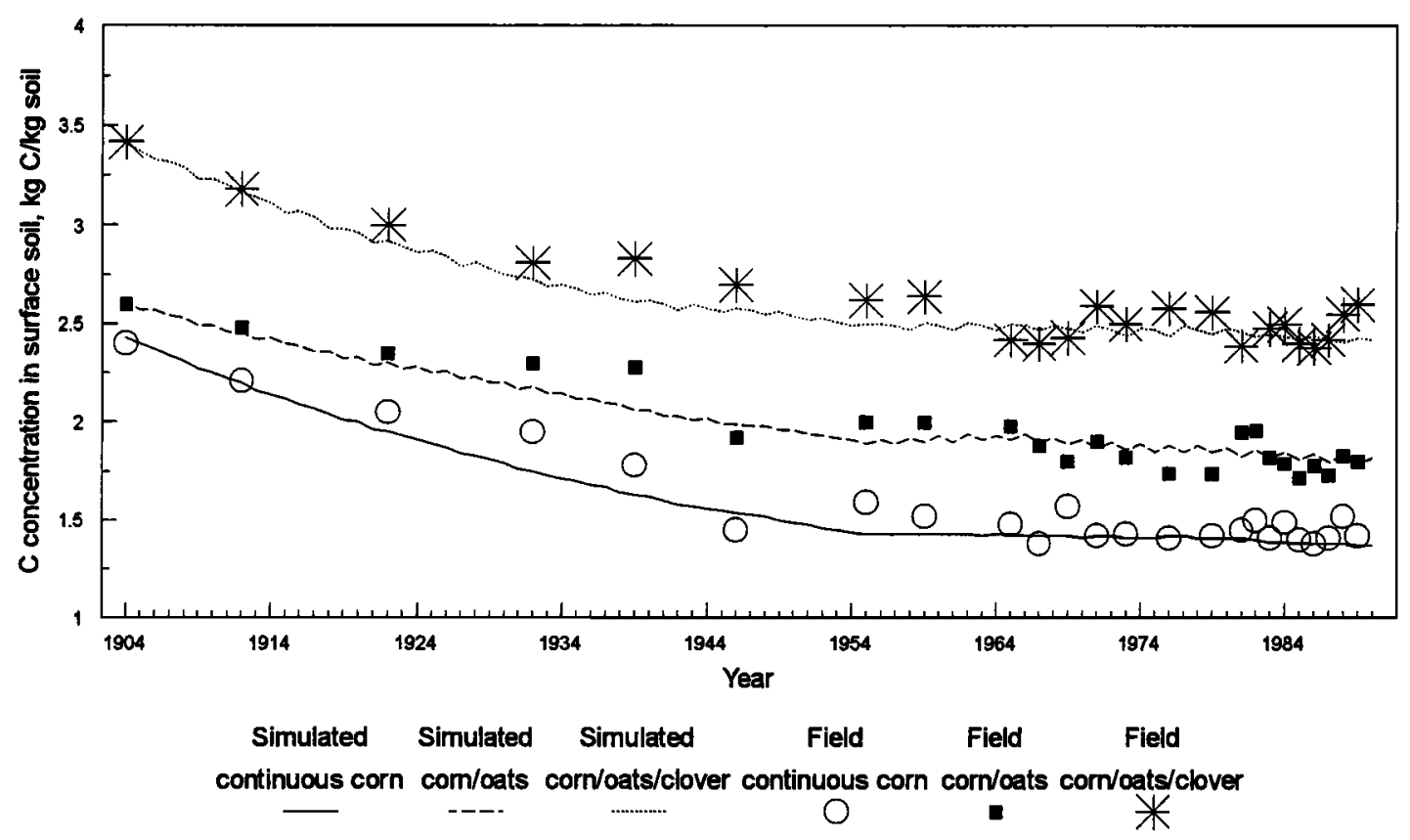

Figure 7. Simulated and measured [USDA, 1984, 1992; Odell et al., 1984] SOC contents in the surface soil $(0-15 \mathrm{~cm})$ at three plots at the Morrow Plots Agricultural Experimental Station at Urbana, Illinois, from 1904 to 1990 . The three plots were under continuous com, com/oats, and corn/oats/clover rotations during the 86-year period. Neither fertilizer nor manure was applied on the three plots. Both the simulated and field results show that SOC storage cannot increase without adequate available nitrogen supplied to the soils. The decrease in SOC storage was mitigated from 1955 because of the change in residue management. 
practices that occurred in 1955 was in residue management. In the simulations $40 \%$ of aboveground residues were left in the field before 1955 and $90 \%$ after 1955. All belowground crop residues (roots) are considered to be left in the soil at harvest. Both the simulated and field results also show that SOC storage cannot increase without adequate available $\mathbf{N}$ supplied to the crop plots. If nitrogen supply is inadequate, crop yield decreases, and therefore so does the amount of residue carbon returned to the soil. This will cause a gradual decline in the soil carbon pool.

\section{Case 6: 150-Year Soil C Storage Dynamics in Cropland in England}

The Rothamsted Agricultural Experiment Station is located at Harpenden, United Kingdom, $\sim 45 \mathrm{~km}$ from London. Its longterm field experiments provide an important opportunity for studying the dynamics of organic matter in soils. Three plots were chosen from the Rothamsted experiments to validate the DNDC model. On the three plots, manuring and cropping have remained substantially unchanged since 1840 [Jenkinson, 1991].

Plots 03,08 , and 22 are located within the same continuous winter wheat field (Broadbalk). From 1840 to 1990 , plot 03 was unmanured and unfertilized, plot 08 was fertilized with $144 \mathrm{~kg} \mathrm{~N} \mathrm{ha}^{-1} \mathrm{y}^{-1}$, and plot 22 was manured with $35 \mathrm{t}$ farmyard manure (equivalent to $3,000 \mathrm{~kg} \mathrm{C} \mathrm{ha}^{-1} \mathrm{y}^{-1}$ ). The plots were conventionally tilled (plowed once after harvest and disked once before planting). All three plots were fallowed every fifth year from 1925 to 1965 . During the fallow years, the plots were not manured, fertilized, or tilled. Soil texture is loam, $p \mathrm{H}$ is $\sim 7$, and SOC content was $\sim 31,000 \mathrm{~kg} \mathrm{C} \mathrm{ha}^{-1}$ in 1840 [Jenkinson, 1990].

For the simulation, a 150-year climate scenario was constructed by recycling 10-year climate data (1971-1980) for London, United Kingdom [USDC, 1987]. A 150-year simulation was conducted for each plot with its cropping practices. Both the simulated results and field data show the significant effects of manure amendment and fertilization on long-term SOC dynamics (Figure 8). On the manured plot, SOC storage continuously increased from 1840 to 1990 , except in the fallow years. The trend still continues even though the current SOC level is more than twice the initial level. On the fertilized plot the SOC storage has been relatively stable, implying that the nitrogen inputs (predominantly fertilizer) and output (predominantly harvest) are in rough balance. SOC storage usually declines in a cropland losing nitrogen because of reduced plant and therefore residue yield. On the plot without manure amendment or fertilization, SOC storage has slowly decreased. During the fallow years, SOC storage dropped significantly because no fresh residue was added to replenish soil respiration losses. This implies that residue incorporation is a major factor controlling SOC dynamics.

\section{Summary of Validation Studies}

Cases 1 and 2 indicate that the residue decomposition routine in DNDC is acceptable. Although short-term rates may not match field results, the agreement between modeling and measurements seems reasonable at annual (and longer) timescales.

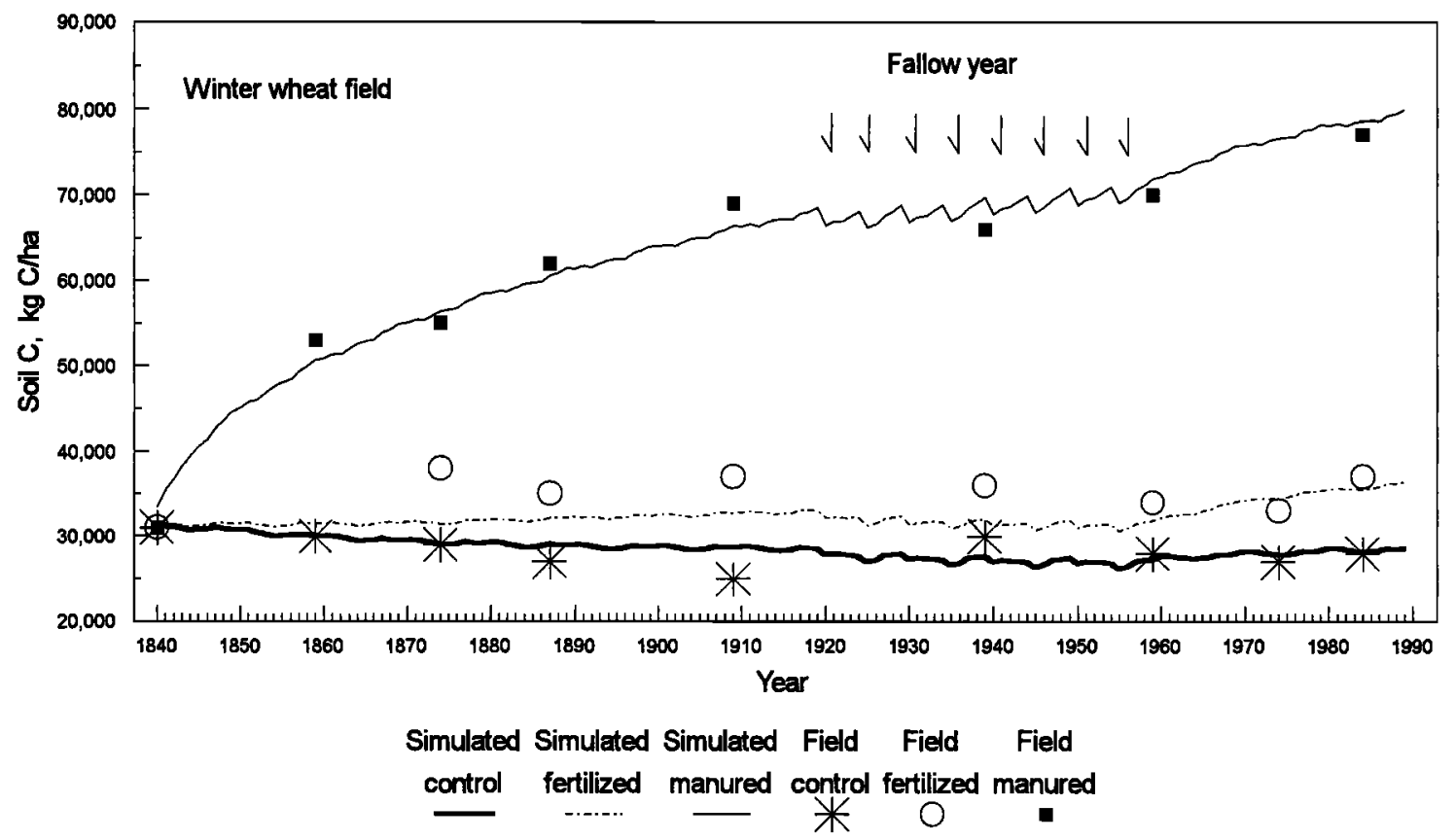

Figure 8. Simulated and measured [Jenkinson, 1991] SOC contents at three plots with different cropping practices in a winter wheat field at the Rothamsted Agricultural Experimental Station in England from 1840 to 1990. On the control plot on which neither fertilizer nor manure was supplied the SOC storage continuously decreased. On the fertilized plot the SOC storage has been relatively stable implying that the $\mathrm{N}$ input and output are in rough balance. On the manured plot, SOC storage continuously increased from 1840 to 1990 , except in the fallow years. 
Table 3. Ranges of Variation in Climate/Soil Conditions

\begin{tabular}{lcl}
\hline \multicolumn{1}{c}{ Parameter } & Standard & \multicolumn{1}{c}{ Range } \\
\hline Annual temperature, ${ }^{\circ} \mathrm{C}$ & 9.4 & $5.4,7.4,11.4,13.4$ \\
Annual precipitation, cm & 82.50 & $21.54,52.02,112.98,143.46$ \\
Soil texture & silty clay & sand, sandy loam, loam, \\
& loam & sandy clay, clay \\
Soil $p \mathrm{H}$ & 6.0 & $4.0,5.0,7.0,8.0$ \\
Soil organic $\mathrm{C}, \mathrm{kg} \mathrm{C} / \mathrm{kg}$ & 0.02 & $0.001,0.01,0.03,0.04$ \\
\hline
\end{tabular}

Cases 3 and 4 show that DNDC captures the strong seasonality of soil respiration, implying that its soil climate controls on microbial and root respiration rates are adequate. Cases 5 and 6 demonstrate that DNDC is able to simulate long-term behavior of soil carbon pools for a variety of crops and agricultural practices. The following section will now use DNDC to investigate the sensitivity of the agroecosystem carbon balance to a variety of agricultural practices.

\section{Sensitivity of Soil Carbon to Changing Climate, Soils, and Agricultural Practices}

The sensitivity studies reported here were designed to illustrate how the DNDC model is used to evolve strategies for conserving and sequestering carbon in agricultural soils. The results reported here are primarily based on scenarios designed to study the response of soil carbon in com (maize) plots to effects of changes in tillage, fertilization rates, manure amendment, and irrigation practices typical of those used in the United States. The SOC response to a change from one agricultural practice to another is simulated for a range of climate and soil conditions. The climate conditions used in our simulations reflect gradients equivalent to growing season conditions ranging from Maine to Florida [USDA, 1987]. The complete set of climate and soil conditions used as model inputs for sensitivity studies are listed in Table 3. Certainly, there are some scenarios where corn plant growth is poor, and these conditions would not be representative of areas where large-scale corn production takes place in the United States. However, these scenarios are often valuable for understanding the biogeochemical processes which influence organic carbon dynamics.
The agricultural practice scenarios used for our sensitivity analysis are described in Table 4 . These practices are typical of those used on corn crops in the United States [USDA, 1990; Sutton et al., 1983]. A one-year simulation was conducted for each agricultural practice scenario, holding all but one of the climate or soil variables constant. For example, conventional tillage was run using the standard condition, then rerun varying temperature, precipitation, soil texture, $\mathrm{pH}$, and initial SOC content individually using the ranges given in Table 3 . The next step was a comparison of each practice to the standard run to determine the relative effect on SOC of varying each environmental parameter. For each simulation the model calculates $\mathrm{CO}_{2}$ emissions, corn crop residue yields, changes in the column SOC content, and numerous other variables [ $\mathrm{Li}$ et al., 1992a]. The changes in SOC resulting from changes in agricultural practices in various climate regimes and soil conditions are illustrated in Figure 9. The bars in the figure represent the difference in SOC storage between the baseline agricultural practice and the modified practice (Table 4). The actual values of the net change in SOC storage, the crop residue production, and the total soil respiration for the one-year scenarios are listed in Table 5.

\section{Effect of Organic Amendments}

It is not a surprise, but important to quantify, that by far the largest gains in SOC result from manure amendments (Figure 9a). Adding $2,000 \mathrm{~kg} \mathrm{C} \mathrm{ha}^{-1}$ by manuring increased total SOC at the end of the year by approximately $1,450-3,100 \mathrm{~kg} \mathrm{C} \mathrm{ha}^{-1}$. In 17 of the 21 scenarios run the manure amendments increased crop residue production sufficiently to produce a synergistic effect on carbon sequestration in the soil (i.e., sequestration greater than the added $\left.2000 \mathrm{~kg} \mathrm{C} \mathrm{ha}^{-1}\right)$. The most important

Table 4. Agricultural Practice Scenarios for Sensitivity Analysis

\begin{tabular}{lllllcc}
\hline & \multicolumn{6}{c}{ Agricultural Practice Scenario } \\
\cline { 2 - 7 } Practice & BA & CS & NT & EF & MA & IR \\
\hline Tillage & plow & disk & mulch & plow & plow & plow \\
$\begin{array}{c}\text { Fertilizing, } \\
\text { kg N/ha }\end{array}$ & 50 & 50 & 50 & 150 & 50 & 50 \\
$\begin{array}{c}\text { Manuring, } \\
\text { kg C/ha }\end{array}$ & 0 & 0 & 0 & 0 & 2000 & 0 \\
Irrigation, cm & 0 & 0 & 0 & 0 & 0 & $5 * 5$ \\
\hline
\end{tabular}

a BA, baseline; CS, conservation tillage; NT, no-till; EF, enhanced fertilization; MA, manure amendment; IR, irrigation scenario. 
variables in this experiment were soil texture and the initial SOC content. In sand, sandy loam, and loam soils aerobic oxidation of added manure and crop residues reduces the net gain in SOC relative to fine-grained sandy clay and clay soils. At a relatively high initial SOC content of $0.04 \mathrm{~kg} \mathrm{C} \mathrm{kg}^{-1}$ soil the effect of a manure amendment on crop residue production is reduced, lowering the gross input of organic matter to the soil. These DNDC results are in general agreement with field data on the effects of manuring. As mentioned earlier, the only plot to show a long-term increase in SOC in the Rothamsted experiments was the manured plot (Figure 8). The 86-year continuous corn plots at Urbana which were manured showed the slowest rates of decline in SOC [Odell et al., 1984]. It is generally accepted that with soil, climate, and other factors the same, farmers using manure in place of chemical fertilizer achieve a higher organic content in their soils [Oelhaf, 1978; Power, 1987].

\section{Effect of Increased Fertilization}

The effects on SOC of increasing fertilization rates from $50 \mathrm{~kg} \mathrm{~N} \mathrm{ha}^{-1}$ to $150 \mathrm{~kg} \mathrm{~N} \mathrm{ha}^{-1}$ (as ammonium) in a conventional farming scenario are illustrated in Figure $8 \mathrm{~b}$. There is an increase in SOC storage in all cases except on the sandy soil. It is important to note that the relative increases in SOC storage due to increased fertilization are always smaller than gains calculated for the same soil or climate conditions in the manure amendment scenarios. The increase in SOC sequestration is sensitive to variations in precipitation, soil texture, and the initial SOC content. The more than 10-fold increase in SOC sequestration resulting from high fertilization at $140 \mathrm{~cm}$ of annual rainfall compared to $20 \mathrm{~cm}$ reflects the increased rate of residue production relative to decomposition (Table 5). In the case of soil texture a relatively rapid decline in decomposition rate occurs in finer grained soils compared to rates of change in residue production, raising net $S O C$ increase in sandy clay and clay soils. At low initial SOC the increased fertilizer input is converted primarily into residue production with only a small effect on decomposition rates (Figure 9b, Table 5). These results are again compatible with the Rothamsted experiments which showed slightly higher SOC in fertilized plots compared to controls (Figure 8).

\section{Effects of Changing from Conventional Tillage to No-Till}

The magnitude of the SOC response to a change in tillage is relatively small except for sand and sandy loam soils where a substantial increase results from a change to no-till (Figure $9 c)$. In these cases the residue production rates are similar, but decomposition rates are considerably higher in conventional tillage (Table 5). These experiments also indicate that a shift from conventional to no-till agriculture may have little or no benefit for SOC sequestration at low levels of precipitation in clay soils or in low carbon soils. In every scenario run the decomposition rate of SOC is lower in the no-till environment, as would be expected since conventional plowing breaks down macroaggregates and aerates soil, enhancing decomposition [Elliott, 1986]. However, in clay soils with a low carbon content in an arid climate the release of nitrogen from decomposition stimulates residue production at rates that exceed the reduced rates of decomposition in the no-till comparison. It is important to keep in mind that no-till techniques impact other environmental considerations that are not being considered in this study.
For example, field studies in Maryland indicated that changing from conventional to no-till reduced leaching of nitrates beyond the root zone [Angle et al., 1993].

\section{Effects of Irrigation}

Irrigation is an important contributor to agricultural production, especially in semiarid regions and in areas of intensive year-round production. There are $\sim 220$ million hectares of irrigated land worldwide; 34 million hectares of U.S. farmland are irrigated [Van Der Leeden et al., 1990]. DNDC sensitivity studies of irrigation resulted in relatively small changes in SOC sequestration rates (Figure 9d). The most pronounced effects of irrigation are observed across the precipitation gradient studied. At 22 and $52 \mathrm{~cm}$ precipitation per year the addition of $25 \mathrm{~cm}$ of irrigation water resulted in a significant increase in residue production relative to decomposition rates, while at higher levels of precipitation nitrates are leached from the soil by added irrigation water, and residue production decreases sufficiently to result in significant losses of SOC (Table 5 , Figure 9d). There are few systematic studies on the effect of irrigation on SOC. One study in the Nebraska sandhill soils found no significant difference in the carbon content of irrigated and nonirrigated surface soils but did find an increase of 750 $\mathrm{kg} \mathrm{Cha}^{-1}$ at the 75-150 mm depth interval [Lueking and Schepers, 1985].

\section{Limitations}

This analysis has focused on the need to test and document DNDC for studies of the sensitivity of soil $\mathrm{C}$ to climatic and agricultural practice variables. In previous papers we have reported DNDC results for the sensitivity of $\mathrm{N}_{2} \mathrm{O}$ emissions to similar variables [Li et al., $1992 \mathrm{a}, \mathrm{b} ; 1$ 1994]. The separate reporting of individual outputs from the fully integrated DNDC model of $\mathrm{C}$ and $\mathrm{N}$ processes in agricultural soils was necessary to meet journal standards for paper length. Now that the basic equations and heritage of DNDC are easily available, future studies will pursue more comprehensive reporting of the integrated response of agricultural ecosystems to changes in climate and use patterns.

A significant limitation in DNDC which remains to be addressed is the lack of a capability for addressing physical erosion effects on $\mathrm{C}$ and $\mathrm{N}$ dynamics and processes. The test and validation results reported in this and previous DNDC papers involved sites with relatively little relief. Data from temperate zone agricultural experiment stations are preferred for model testing due to their long and well-documented records. However, they are also typically sited in optimal locations for agriculture. Food production systems worldwide frequently encroach on lands which are marginal for agriculture due to variable relief and significant erosion potential. A next step in the evolution of DNDC will involve coupling to a three-dimensional physical erosion and hydraulic transport submodel.

\section{Long-Term Response of Soil Carbon}

The DNDC simulations discussed above were designed to test short-term responses of soil carbon to changes in agricultural practices. Most farm operations vary considerably on timescales of 1-10 years due to changing market conditions, ownership, and in response to information from advisory services. One consequence of a dynamic agricultural operation is that soil 


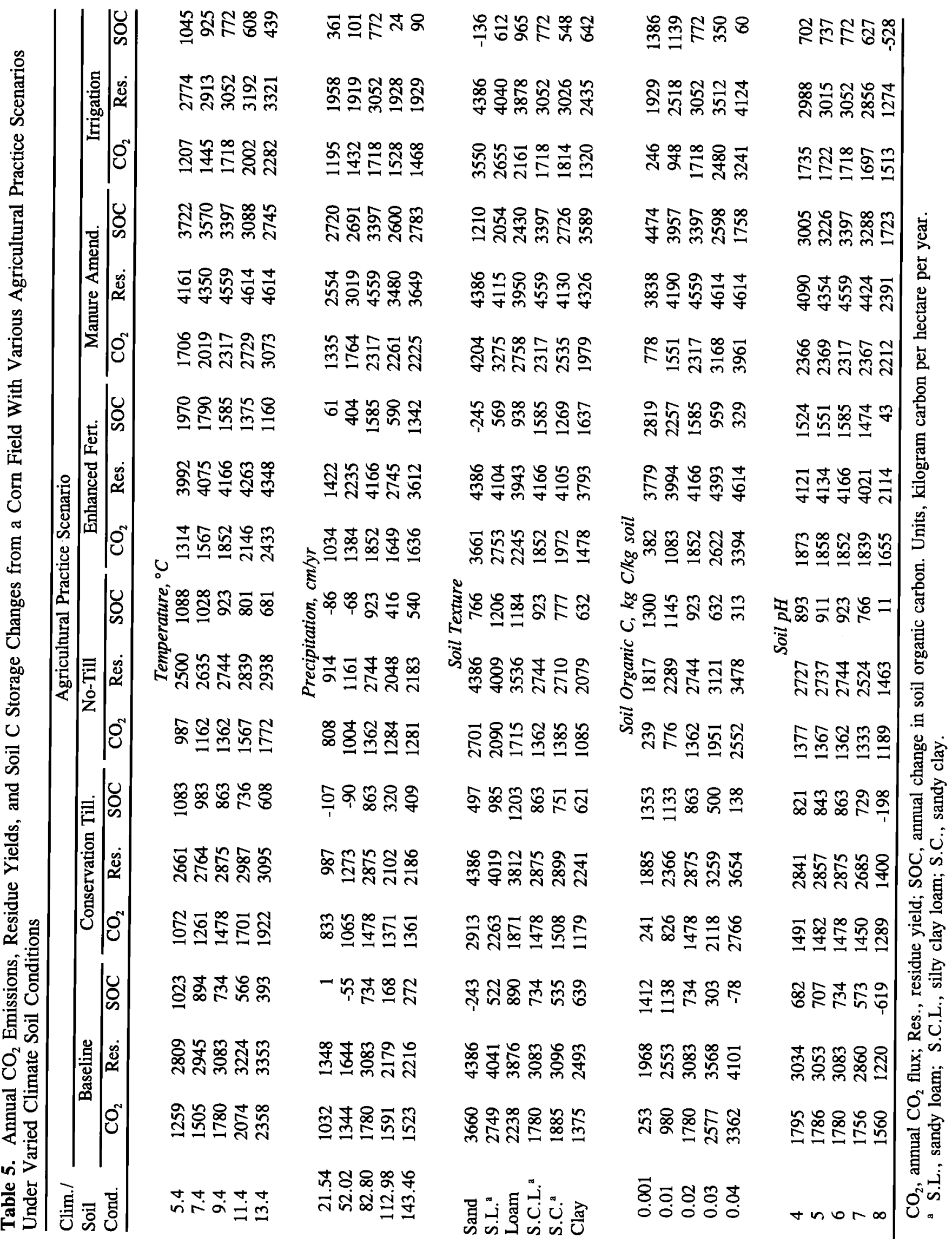



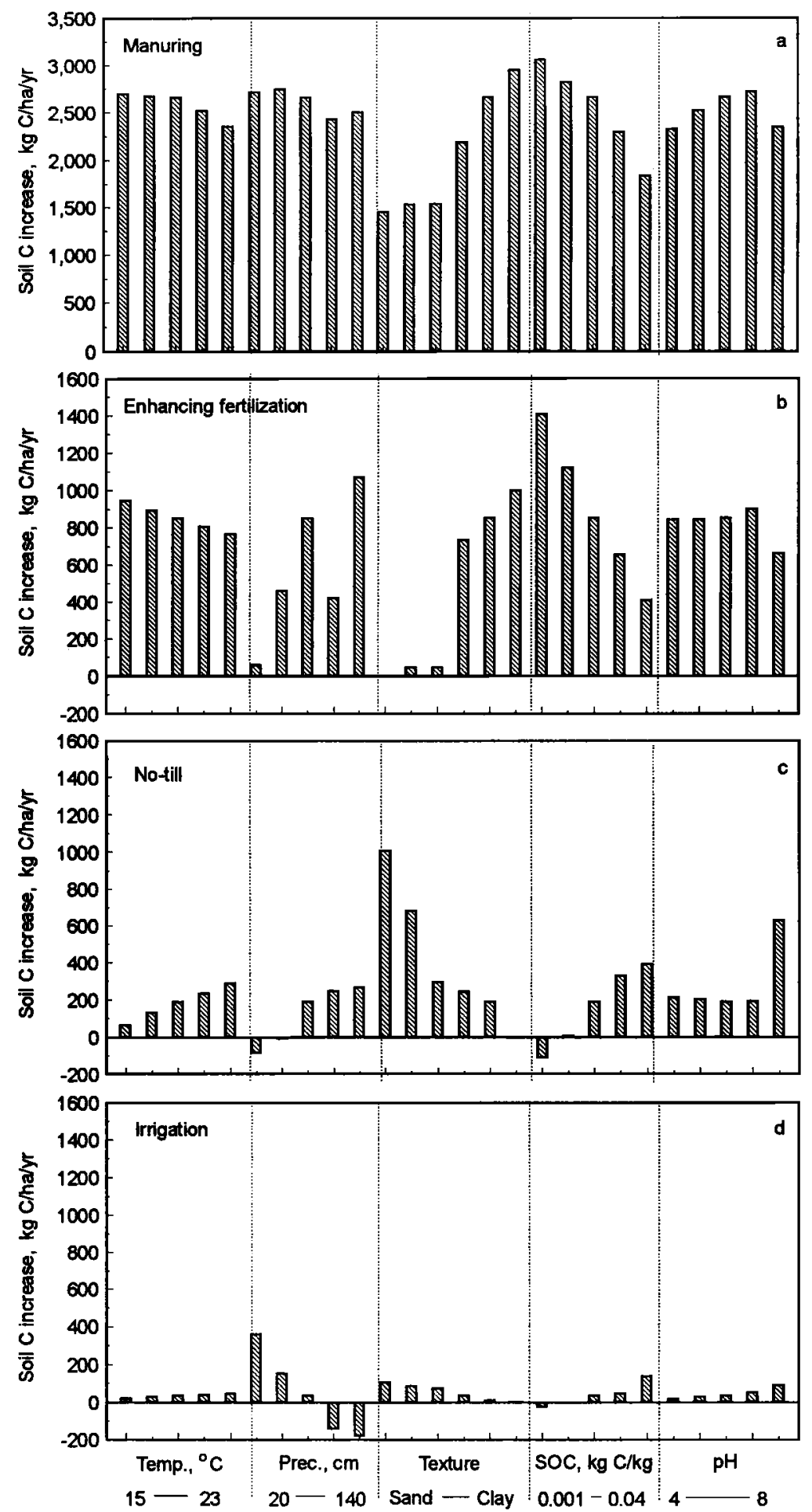

Climate/soil conditions

Figure 9. Sensitivity of change in SOC storage to varied climate/soil conditions under various cropping activity scenarios: (a) manure amendment, (b) increased fertilization, (c) conversion from conventional tillage to no-till, and (d) irrigation. The largest gains in SOC result from manure amendment. The bars represent the difference in SOC storage between the standard conditions and the modified conditions. Absolute values of SOC storage are in Table 5. Note that the vertical axis is scaled differently for graph (a). The fertilizer-induced increase in SOC is sensitive to variations in precipitation, soil texture, and the initial SOC content. The SOC response to a change in tillage is sensitive to soil texture. The magnitude of the SOC response to irrigation is relatively small. The most pronounced effects of irrigation are observed across the precipitation gradient. 
properties determined by slower rate processes (e.g., decomposition) will seldom reach equilibrium. SOC sequestration might exhibit quite different short- versus long-term sensitivities to certain variables. To explore timescales required to reach equilibrium and the consequences of long-term continuity in agricultural practices on $\mathrm{SOC}$ sequestration, a set of 200 -year DNDC simulations was run. For these simulations our standard climate and soil scenarios were used (Table 4). The 200-year climate was generated by repeating the one-year scenario. The effects of agricultural practices and initial SOC content on long-term equilibrium carbon content is illustrated in Figure 10.

The most obvious long-term dynamic is the adjustment of each practice scenario to climate, independent of the initial SOC content over the range studied. The time to equilibrium for the baseline and enhanced fertilization cases is -200 years; the manure and no-till scenarios require an even longer period. These results also demonstrate that the success of a program to sequester atmospheric carbon in agricultural soils will depend on the specific climate condition and the initial SOC content.

The effects of variations in soil texture and temperature on long-term SOC content is illustrated in Figures 11 and 12. The long-term equilibrium SOC increases with decreasing temperature and finer texture (i.e., clay). The time-to-equilibrium depends on both the magnitude and sign of the difference between the initial and equilibrium SOC contents. Typically, decomposition of excess soil carbon (above equilibrium) occurs more rapidly than sequestration of added carbon.

The influence of crop rotation shows the most pronounced impacts on long-term equilibrium SOC contents (Figure 13). The primary determining factor is residue production. Continuous corn produces the highest residues and establishes the highest equilibrium SOC content. Continuous wheat produces relatively little residue and, for the climate and soil scenario run, results in SOC loss over the entire range of initial SOC values simulated. Rotations of corn and wheat or corn and soybean produce intermediate levels of SOC storage. Of course, there are reasons why continuous corn might not be an acceptable strategy for carbon sequestration at many locations (e.g., erosion potential, pest problems, fertilizer and/or water requirements). The model scenarios suggest, though, that significant carbon sequestration will only be accomplished if there are substantial carbon additions to the soil, either as farmyard manure or crop residue.

\section{Summary and Implications}

The U.S. National Action Plan for Global Climate Change includes recommendations for changes in agriculture. Conservation reserve and conservation tillage programs are emphasized [USDS, 1992]. Our DNDC sensitivity studies indicated that, while reducing tillage often (but not always) did enhance carbon storage in the soil (and thus mitigate increasing atmospheric $\mathrm{CO}_{2}$ ), the magnitude of the enhancement was highly dependent on soil and climate conditions (Figure 9). At present there does not appear to be any systematic effort to verify that the current conservation tillage programs sponsored by the 1990 Farm Bill (32 million hectares) are enhancing soil carbon storage.

The sensitivity of soil carbon stocks to climate and agricultural practices and the interactive nature of various practices demands an integrated assessment methodology for effective policy analysis. If enhanced carbon sequestration in agricultural soils is an objective, it is clear that a validated biogeochemical model could play an important role in designing specific policies

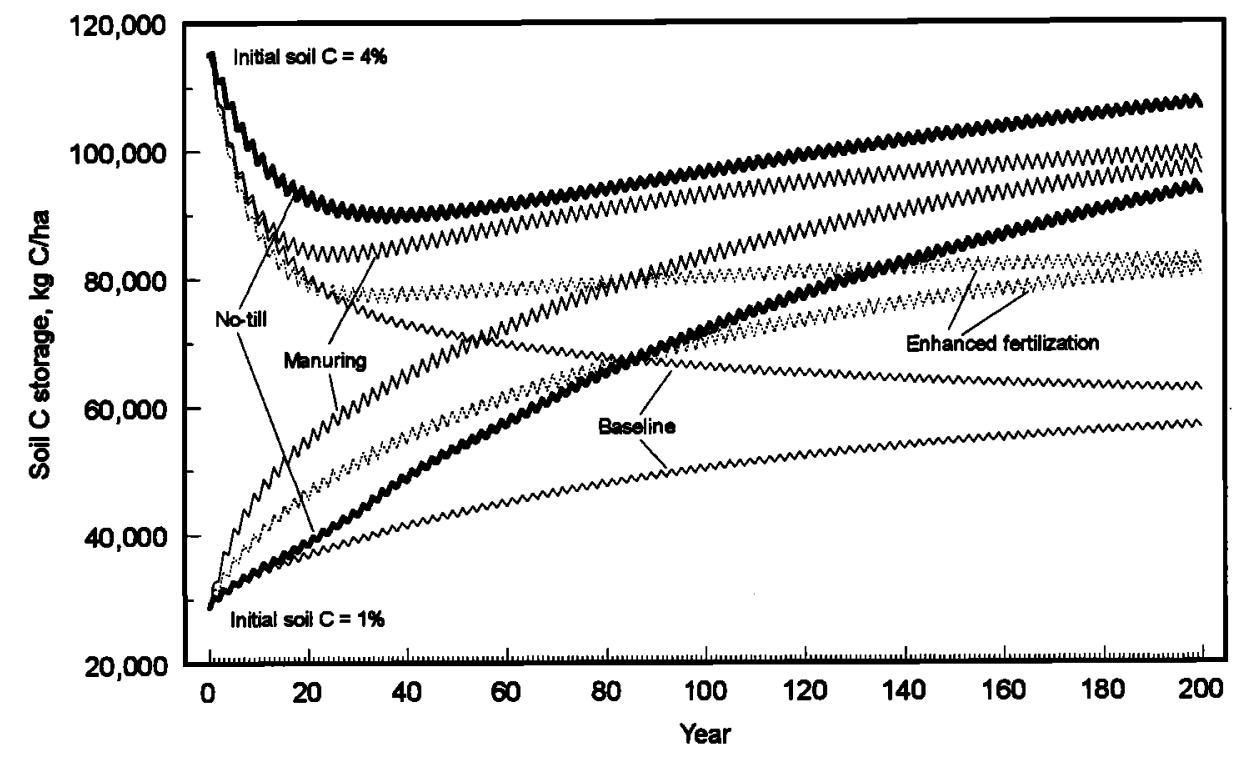

Figure 10. Long-term response of SOC storage to various cropping practices. It takes 200 years or longer for the soils to approach equilibrium. The SOC storage contents at equilibrium are independent of their initial SOC levels but depend on cropping practices. Use of manure or no-till will elevate the SOC storage at long-term equilibrium by about 1.8 times. The soils with different initial SOC contents showed different responses to the practices. The soils with low initial SOC gained the largest SOC by manuring, although no-till was more important for the soils with high initial SOC to sequester atmospheric carbon. 


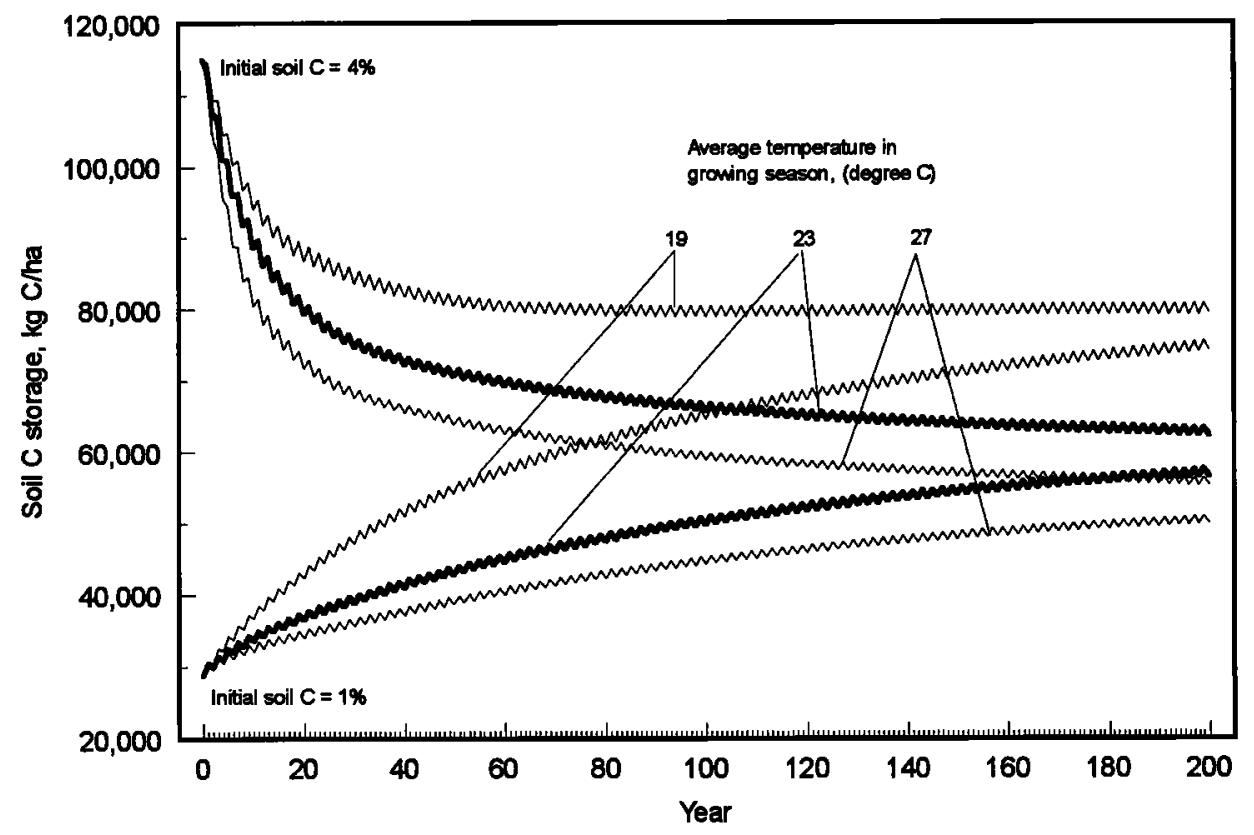

Figure 11. Long-term response of SOC storage to temperature. Under the simulated conditions, when growing season average temperature increased by $4^{\circ} \mathrm{C}$ from 23 to $27^{\circ} \mathrm{C}$ the SOC content at equilibrium decreased by $10 \%$. When growing seacon average temperature decreased by $4^{\circ} \mathrm{C}$ from 23 to $19^{\circ} \mathrm{C}$ the SOC content at equilibrium increased by $30 \%$.

appropriate to the soils, climate, and agricultural conditions of a local or regional area. In some cases reduced tillage might be the most effective measure, in others enhanced $\mathrm{N}$ fertilization (perhaps with more effective timing and placement of fertilizers)may be appropriate. Such assessments would also include other considerations like nitrate leaching into groundwater and soil erosion. In addition, it will be important to consider the interactions of the hundred-year timescale of soil carbon equilibration and the relatively more rapid changes induced by agricultural practices. It is likely that most agricultural soils are not in equilibrium with respect to carbon storage. Those soils furthest from equilibrium will have the greatest potential

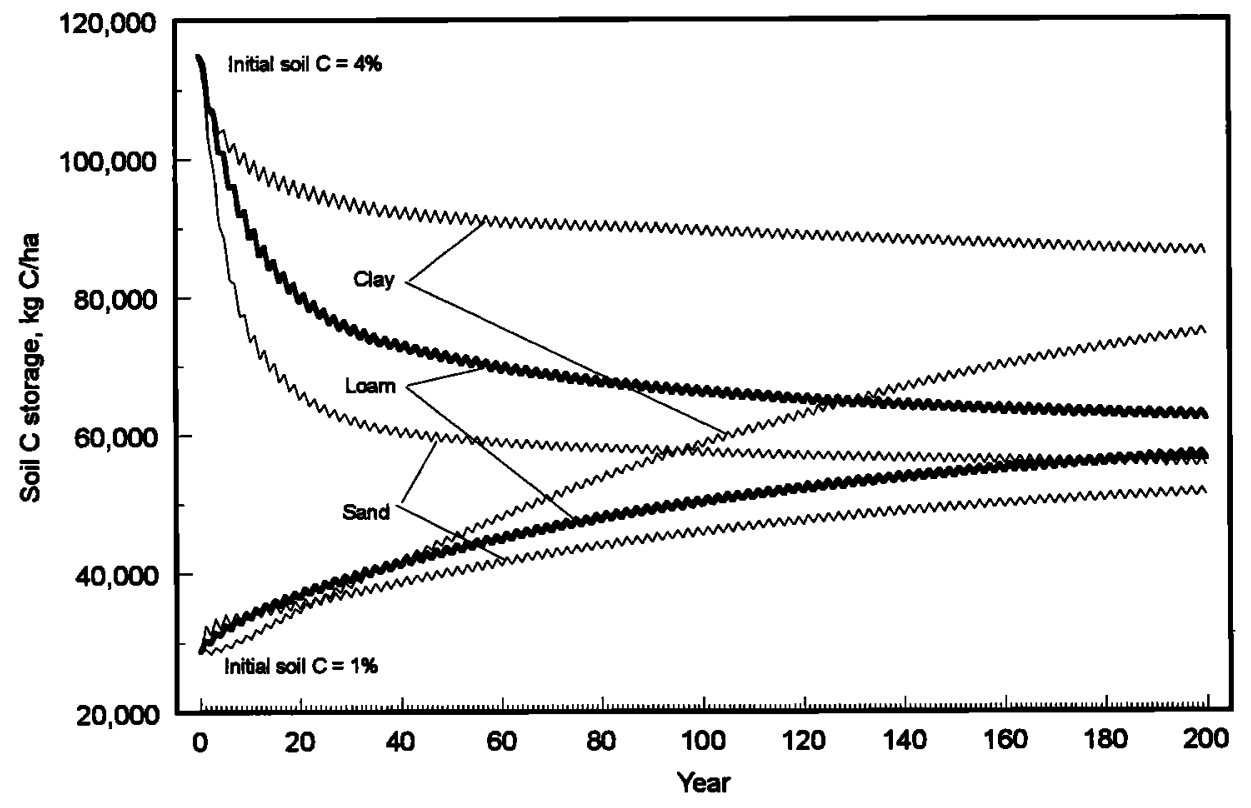

Figure 12. Long-term response of SOC storage to soil texture. The clayey soils will gain more carbon than the sandy or loamy soils at long-term equilibrium under same climate/practice conditions. 


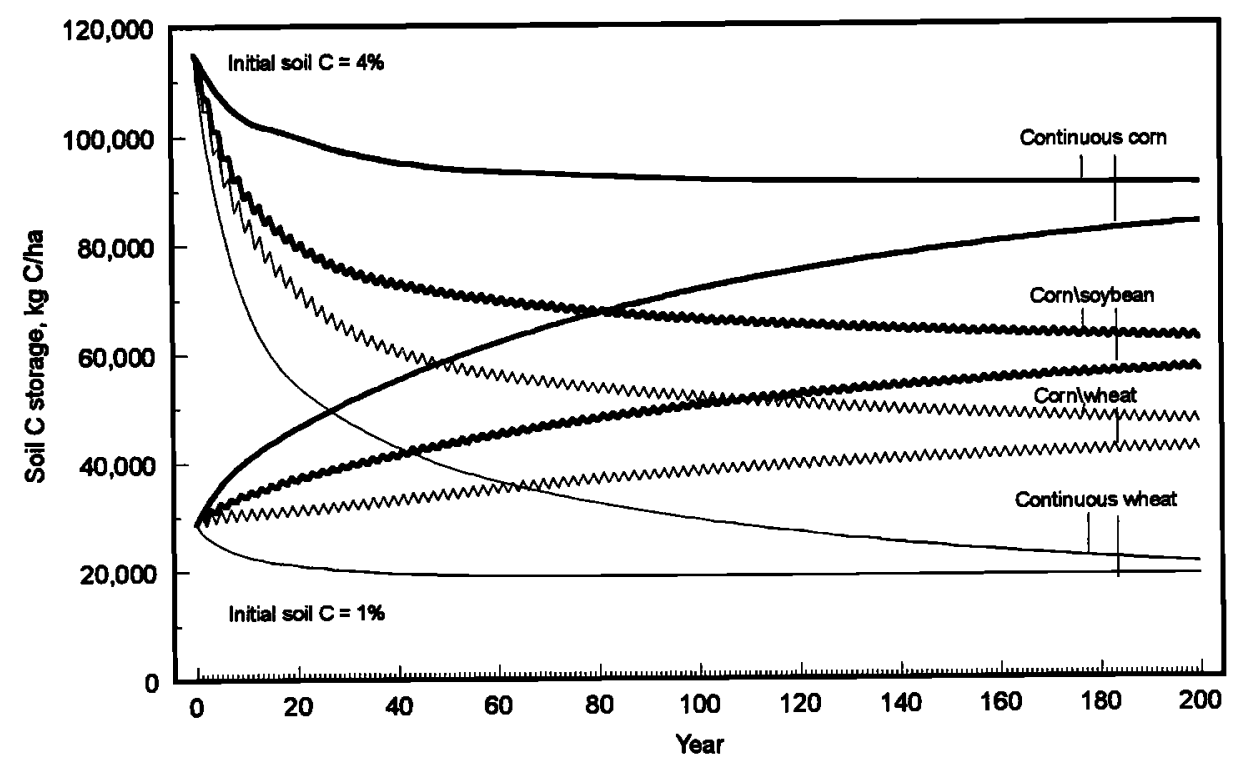

Figure 13. Long-term response of SOC storage to crop rotations. Crop rotations affect SOC storage at equilibrium by their specific residue yields and practices. Continuous corn rotation showed the largest SOC storage at equilibrium because of its highest average annual residue yield.

for short-term carbon losses or gains. Short-term field studies may be insensitive to the effects of long-term, climate-driven processes.

Acknowledgments. We would like to thank Ted Peck (Cooperative Ext. Serv., U. Illinois), Wayne Wendland (Illinois State Climatologist), and David Jenkinson (Rothamsted Exp. Station) for sharing data and for helpful advice. Pam Matson and an anonymous reviewer provided important comments which significantly improved the quality of this paper. Financial support for this work was provided by the U.S. Environmental Protection Agency and the NASA EOS Interdisciplinary Research Program.

\section{References}

Angle, J.S., C.M. Gross, R.L. Hill, and M.S. McIntosh, Soil nitrate concentrations under corn as affected by tillage, manure, and fertilizer applications, J. Environ. Qual., 22, 141-147, 1993.

Barnwell, T.O., et al., An approach to assessment of management impacts on agricultural soil carbon, Water Air Soil Pollut., 64, 423-435, 1992.

Bauer, A., and A.L. Black, Soil carbon, nitrogen, and bulk density comparison in two cropland tillage systems after 25 years and in virgin grassland, Soil Sci. Soc. Am. J., 45, 1166-1170, 1981.

Bijay-Singh, J.S., and S.R. Gupta, Plant decomposition and soil respiration in terrestrial ecosystems, Bot. Rev., 43, 449-528, 1977.

Boois, H.M., Measurement of seasonal variations in the oxygen uptake of various litter layers of an oak forest, Plant Soil, 40, 545-555, 1974.

Brown, L.R., Facing food insecurity, in State of the World 1994, edited by L. Starke, pp. 177-197, W.W. Norton, New York, 1993.
Buyanovsky, G.A., and G.H. Wagner, Post-harvest residue input to cropland, Plant Soil, 93, 57-65, 1986.

Buyanovsky, G.A., G.H. Wagner, and C.J. Gantzer, Soil respiration in a winter wheat ecosystem, Soil Sci. Soc. Am. J., 50, 338-344, 1986.

Campbell, C.A., Soil organic carbon, nitrogen and fertility, in Soil Organic Matter, Dev. in Soil Sci., Vol. 8, edited by M. Schnitzer, and S.U. Khan, pp. 173-271, Elsevier Amsterdam, Netherlands, 1978.

Detwiler, R.P, and C.A.S. Hall, Tropical forests and the global carbon cycle, Science. 239, 42-47, 1988.

Doran, J.W., Soil microbial and biochemical changes associated with reduced tillage, Soil Sci. Soc. Am. J., 44, 765-771, 1980.

Dorr, E., and K.O. Munnich, Annual variation in soil respiration in selected areas of the temperate zone, Ser. B Dyn. Meteorol. Oceanogr., 39, 114-121, 1987.

Elliott, E.T., Aggregate structure and carbon, nitrogen, and phosphorus in native and cultivates soils, Soil Sci. Soc. Am. J., 50, 627-633, 1986.

Erickson, A.E., Tillage effects on soil aeration, in Predicting Tillage Effects on Soil Physical Properties and Processes, edited by P.W. Unger and D.M. Van Doren, ASA Special Publ. No. 44, Am. Soc. of Agron., Madison, Wis., 1982.

Foth, H.D., Root and top growth of corn, Agron. J., 54, 49-52, 1962

Fox, R.H., and V.A. Bandel, Nitrogen utilization with notillage, in No-Tillage and Surface-Tillage Agriculture, edited by M.A. Sprague and G.B. Triplett, pp. 117-148, Wiley-Interscience, New York, 1986.

Hamilton, S.D., C.J. Smith, P.M. Chalk, and P. Hopmans, A model based on measurement of soil and plant ${ }^{15} \mathrm{~N}$ enrichment to estimate $\mathrm{N}_{2}$ fixation by soybean (Glycine Max L. Merrill) grown in pots, Soil Biol. Biochem., 24, 71-78, 1992.

Houghton, R.A., J.E. Hobbie, J.M. Melillo, B. Moore, B.J. Peterson, G.R. Shaver, and G.M. Woodwell, Changes 
in the carbon content of terrestrial biota and soils between 1860 and 1980: A net release of $\mathrm{CO}_{2}$ to the atmosphere, Ecol. Monogr., 53, 235-262, 1983.

Houghton, R.A., G.M. Woodwell, R.A. Sedjo, R.P. Detwiler, C.A.S. Hall, and S. Brown, The global carbon cycle, Science, 241, 1736-1739, 1988.

Instituto Meteorologico Nacional, Catastro de las seies de precipitaciones, Año del Centenario, Minist. de Recursos Nat., Energ. y Minas, 1888-1988. Medidas en Costa Rica, San Jose, Costa Rica, 1988.

Jackson, R.B., On estimating agriculture's net contribution to atmospheric carbon, Water Air Soil Pollut., 64, 121-137, 1992.

Jenkinson, D.S., The turnover of organic carbon and nitrogen in soil, Philos. Trans. $R$. Soc. London B, 329, 361-368, 1990.

Jenkinson, D.S., The Rothamsted long-term experiments: Are they still of use? Agron. J., 83, 2-10, 1991.

Kucera, C.L., and D.L. Kirkham, Soil respiration studies in tallgrass prairie in Missouri, Ecology, 52, 912-915, 1971.

$\mathrm{Li}, \mathrm{C}$., S. Frolking, and T.A. Frolking, A model of nitrous oxide evolution from soil driven by rainfall events, 1 , Model structure and sensitivity, J. Geophys. Res., 97, 9759-9776, $1992 \mathrm{a}$.

Li, C., S. Frolking, and T.A. Frolking, A model of nitrous oxide evolution from soil driven by rainfall events, 1 , Model applications, J. Geophys. Res., 97, 9777-9783, 1992 b.

Li, C., S. Frolking, R. Harriss, and R. Terry, Modeling nitrous oxide emissions from agriculture : A Florida case study, Chemosphere, in press, 1994.

Linn, D.M., and J.W. Doran, Aerobic and anaerobic microbial populations in no-till and plowed soils, Soil Sci. Soc. Am. J., 48, 794-799, 1984.

Lueking, M.A. and J.S. Schepers, Changes in soil carbon and nitrogen due to irrigation development in Nebraska's sandhill soils, Soil Sci. Soc. Am. J., 49, 626-630, 1985.

Lugo, A.E., M.J. Sanchez, and S. Brown, Land use and organic carbon content of some subtropical soils, Plant Soil, 96, 185-196, 1986.

Macfayden, A., Soil metabolism in relation to ecosystems energy flow and to primary and secondary production, in Methods of Study in Soil Ecology, edited by J. Phillipson, pp. 167-172, International Biological Programme, Paris, 1970.

Molina, J.A.E., C.E. Clapp, M.J. Shaffer, F.W. Chichester, and W.E. Larson, NCSOIL, a model of nitrogen and carbon transformations in soil: Descrilption, calibration, and behavior, Soil Sci. Soc. Am. J., 47, 85-91, 1983.

Molz, F.J. and I. Remson, Extraction term models of soil moisture use by transpiring plants, Water Resour. Res., 6, 1346-1356, 1970.

Monteith, J.L., G. Sceicz, and K. Yabuky, Crop photosynthesis and the flux of carbon dioxide below the canopy, J. Appl. Ecol., 1, 321-327, 1964.

Morris, J.T., and W.H. Dacey, Effects of $\mathrm{O}_{2}$ on ammonium uptake and root respiration by Spartina alterniflora, Am. J. Bot., 71, 979-985, 1984

National Acid Precipitation Assessment Program (NAPAP), Interim assessment: The causes and effects of acidic deposition: Volume III, Atmospheric processes, Washington, D.C., 1988.

Odell, R.T., S.W. Melsted, and W.M. Walker, Changes in organic carbon and nitrogen of Morrow Plot soils under different treatments, 1904-1973, Soil Sci., 137, 160-171, 1984.

Oelhaf, R.C., Organic Agriculture, Allanheld and Osmun, Montclair, N.J., 1978.

Olson, R.A., and L.T. Kurtz, Crop nitrogen requirements, utilization, and fertilization, in Nitrogen in Agricultural Soils,
Agron. Monog., Vol. 22, edited by F.J. Stevenson, Agron.

Soc. Am., Madison, Wis., 1982.

Osman, A.M., Root respiration of wheat plants as influenoed by age, temperature, and irradiation of shoot, Photosynthetica, $5,107-112,1971$.

Paustian, K. W.J. Parton, and J. Persson, Influence of organic amendments and $\mathrm{N}$-fertilization on soil organic matter in long-term plots: Model analyses, Soil Sci. Soc. Am. J., 56, 476-488, 1992.

Power, J.F., Legumes: Their potential role in agricultural production, Am. J. Alternative Agric., 2, 69-73, 1987.

Reganold, J.P., L.F. Elliot, and Y.L. Unger, Long-term effects of organic and conventional farming on soil erosion, Nature, 330, 370-372, 1987.

Sauerbeck, D.R., and M.A. Gonzalez, Field decomposition of carbon-14-labelled plant residues in various soils of the Federal Republic of Germany and Costa Rica, IAEA-SM-211/18, pp. 159-169, Int. At. Energy Agency, Vienna, Austria, 1977.

Schlesinger, W.H., Changes in soil carbon storage and associated properties with disturbance and recovery, in The Changing Carbon Cycle: A Global Analysis, edited by J.R. Trabalka and D.E. Reichle, pp. 194-220, Springer-Verlag, New York, 1986.

Stevenson, F.J, Cycles of Soil: Carbon, Nitrogen, Phosphorus, Sulfur, Micronutrients, Wiley-Interscience, New York, 1986.

Sutton, A.L., D.W. Nelson, and D.D. Jones, Utilization of Animal Manure as Fertilizer, $I D-101$, Coop. Extension Serv., Purdue Univ., West Lafayette, Indiana, 1983.

Tate, R.L., Soil Organic Matter: Biological and Ecological Effects, Wiley-Interscience, New York, 1986.

Tivy, J., Agricultural Ecology, pp. 106-107, Longman Scientific and Technical, England, 1990.

Turpin, H.W, The carbon dioxide of the soil air, Memo $V$, 32, pp. 315-362, Cornell Univ. Agric. Exp. Stn. Memo, Ithaca, New Y., 1920.

U. S. Deptartment of Agriculture (USDA), The Morrow plots: A century of learning, Bull. 775, pp. 1-22, Agric. Exp. Stn., Coll. of Agric., Univ. of Ill. at Urbana-Champaign, Illinois, Bulletin 775, 1984.

U. S. Deptartment of Agriculture (USDA), Major world crop areas and climatic profiles, Ag. Handb. 664, World Agric. Outlook Board, Washington, D.C., 1987.

U. S. Deptartment of Agriculture (USDA), Long-term management effects on soil productivity and crop yield in semi-arid regions of eastern Oregon, Stn. Bull. 675, Agric. Res. Serv. and Agric. Experimental Stn., Oregon State Univ., Columbia Basin Agric. Res. Cent. at Pendleton, Oregon, 1989.

U. S. Deptartment of Agriculture (USDA), Agricultural resources: Inputs situation and outlook report, $A R-17$, Agric. Resour., Washington, D.C., 1990.

U. S. Deptartment of Agriculture (USDA), Agricultural Statistics, U.S. Government Printing Office, Washington, D.C., 1991a.

U. S. Deptartment of Agriculture (USDA), Crop yields as affected by cropping system and rotation, Rep. 516, USDA Agric. Exp. Stn., Mich. State Univ., East Lansing, Mich., $1991 b$.

U. S. Deptartment of Agriculture (USDA), Supplement to The Morrow plots: A century of Learning, Bull. 775, pp. 1-22, Agric. Exp. Stm., Coll. of Agric., Univ. of Ill. at Urbana-Champaign, 1992.

U. S. Deptartment of Commerce (USDC), World weather records, 1971-1980, volume 2, Europe, Natl. Oceanic and Atmos. Admin., Natl. Environ. Satell., Data, and Inf. Serv., Natl. Clim. Data Cent., Asheville, N.C., 1987. 
U. S. Deptartment of State (USDS), National action plan for global climate change, Publ. 10026, 129 pp., Bur. of Oceans, and Int. Environ. and Sci. Aff., Washington, D.C., 1992.

Van Der Leeden, F., F.L. Troise, and D.K. Todd, The Water Encyclopedia, 2nd ed., Lewis, Chelsea, Mich., 1990.

Veen, B.W., Relation between root and root activity, in Structure and Function of Plant Roots, edited by R. Brouwer, et al., pp. 277-280, Martinns Nijhoff/D.W. Junk, London, 1981.

Watts, D.G. and R.J. Hanks, A soil $\mathbf{N}$ model for irrigated corn on sandy soils, Soil Sci. Soc. Am. J., 42, 492-499, 1978.

Wood, C.W., and J.H. Edwards, Agroecosystem management effects on soil carbon and nitrogen, Agric. Ecosyst. Environ., 39, 123-138, 1992.

Young, H.M., Jr., No-Tillage Farming, pp. 17-29. No-Till Farmer, Brookfield, Wis., 1982.

S. Frolking, R. Harriss, and C. Li, Institute for the Study of Earth, Oceans, and Space, University of New Hampshire, Durham, NH03824.(e-mail: stevef@kaos.unh.edu; rch@christa.unh.edu; li@kaos.unh.edu)

(Received October 26, 1993; revised March 8, 1994; accepted March 18, 1994.) 